\title{
11. Sınıf Öğrencilerinin Kimyasal Denge Konusuyla İgili Algoritmik Soruları Çözme Süreçlerinin Sesli Düşünme Protokolü Kullanılarak İncelenmesi
}

Safiye ASLAN, Yrd. Doç. Dr., Aksaray Üniversitesi Eğitim Fakültesi, safiyeaslan@aksaray.edu.tr

Öz: Bu çalışmada, 11. sınıf öğrencilerinin kimyasal denge konusuyla ilgili algoritmik soruları çözme süreçleri incelenmiştir. Araştırma, nitel araştırma yöntemlerinden durum çalışmasıdır. Çalışmaya, Türkiye'nin İç Anadolu Bölgesi'nde yer alan bir Anadolu Lisesi'nin 11. sınıfında öğrenim gören 6 öğrenci katılmıştır. Araştırmanın verileri, 2014-2015 eğitim öğretim yılının ikinci yarıyılında, 11. sınıf kimya dersinde kimyasal denge konusunun işlenmesinden dört hafta sonra toplanmıştır. Veriler, kimyasal denge konusuyla ilgili dört algoritmik soru içeren bir form aracılığıyla yüz yüze görüşülerek toplanmıştır. Öğrencilere algoritmik soru formu verilmeden önce sesli düşünme yönergesi verilmiştir. Ardından öğrencilerden algoritmik soru formunda yer alan soruları, sesli düşünme yönergesinde belirtildiği gibi çözmeleri istenmiştir. Görüşmeler, ses kayıt cihazı kullanılarak kayıt altına alınmıştır. Araştırmanın verilerini öğrencilerin ses kayıtları ve soruların çözümlerini yaptıkları kağıtlar oluşturmuştur. Veriler, betimsel analiz tekniği ile soruda yer alan kavramları ve kavramlar arası ilişkileri tanımlama, değişkenleri/verileri yorumlama, formül/bağıntı kullanma ve algoritma kullanma olmak üzere dört tema altında incelenmiş ve yorumlanmıştır.

Anahtar Kelimeler: algoritmik soru, kimyasal denge, sesli düşünme protokolü

\section{Examination of Algorithmic Problem Solving Processes Related to Chemical Equilibrium of the $11^{\text {th }}$ Grade Students by Using Think-Aloud Protocols}

\begin{abstract}
In this study, the algorithmic problem solving processes related to the subject of chemical equilibrium of the $11^{\text {th }}$ grade students is examined. This is a case study of qualitative research methods. 6 students studying in the $11^{\text {th }}$ grade at an Anatolian High School located in Turkey's Central Anatolia were involved in the study. The data of the study were collected four weeks after studying the chemical equilibrium in the chemistry class of the $11^{\text {th }}$ grade during the second semester of the 20142015 academic year. The data were collected by implementing face to face interviews while filling a form including four algorithmic questions related to chemical equilibrium. Students were given a directive on loud thinking before giving the questionnaire on algorithmic issue. Then the students were asked to solve the problems in the questionnaire of algorithmic questions as it was specified in the directive of loud thinking. Interviews were recorded using a voice recorder. The students' voice records and the papers with problem solving formed the data of the survey. The data is analyzed and interpreted under the four subjects of methods of descriptive analysis, where each question included identifying the concepts and relationships between the concepts, interpretation of variables/data, usage of formulas/equations, and usage of algorithms.
\end{abstract}

Key Words: algorithmic question, chemical equilibrium, think-aloud protocol 


\section{GíRiş}

Günümüz toplumlarının eğitim alanından beklentileri, öğrencilere 21. yüzyıl becerileri olarak adlandırılan becerileri ve yetkinlikleri kazandırması yönündedir. 21. yüzyıl becerileri; yaşam ve kariyer becerileri, öğrenme ve yenilik becerileri ile dijital okuryazarlık becerileri olarak sınıflandırılır (Partnership for $21^{\text {st }}$ Century Learning, 2015-a; Trilling \& Fadel, 2009). Sözü edilen bu beceriler, pek çok alt becerileri ve yetkinlikleri içermektedir. Bunlardan biri de problem çözme becerisidir (Partnership for $21^{\text {st }}$ Century Learning, 2015-b).

Problem çözmeyle bireylerden, farklı türdeki problemleri hem geleneksel hem de yenilikçi yollarla çözmeleri ve farklı bakış açılarını ortaya çıkarmak, daha iyi çözümlere ulaşmak için önemli sorular sormaları beklenmektedir (Partnership for $21^{\text {st }}$ Century Learning, 2015-b). $\mathrm{Bu}$ beklentileri karşılamak için problem çözme becerileri gelişmiş bireyler yetiştirilmesi hedeflenmektedir. Bu bağlamda problem çözme, eğitimciler için önemli bir çalışma alanıdır. Kimya eğitiminde de problem çözme; hem müfredat geliştirmenin önemli bir parçası hem de değerlendirme aracı olarak görülmüş ve kimya eğitimiyle ilgili pek çok araştırmaya konu olmuştur (Mei-Hung, 1993; St Clair-Thompson, Overton \& Bugler, 2012; Temel \& Morgil, 2012). Bu çalışmalar ve okullarda kimya dersleri kapsamında yapılan problem çözme uygulamalarına bakıldığında; problem çözme pratiklerinin genellikle algoritmik ve kavramsal problemler kullanılarak yapıldığı görülmektedir (Coştu, 2007; Gultepe, Yalcin Celik \& Kilic, 2013; Salta \& Tzougraki, 2011). Bu durum aynı zamanda Türkiye'de bir üst öğrenim kademesine geçişte yapılan ulusal sınav sorularında da kendini göstermektedir. Ulusal sınavlarda sorulan soruların genel olarak kavramsal, algoritmik veya grafik soruları olduğu göze çarpmaktadır (Ölçme Seçme ve Yerleştirme Merkezi [ÖSYM], 2013, 2014). Öğretmenler de bu sınavlara öğrencilerini hazırlamak için adı geçen soru tiplerini sıklıkla kullanmaktadır. Bu çalışmaya, bahsedilen soru türlerinden algoritmik sorular konu edinilmiştir.

Algoritmik sorular, öğrencinin bir formülü kullanması veya sayısal bir sonuç bulmak için bir algoritma aracılı̆̆ıyla çalışmasını gerektiren sorulardır (Nakhleh, 1993). Algoritmik soruların kimya dersi kapsamında herhangi bir kimya konusunun işlenişi sırasında kullanılış biçimi çoğunlukla öğrencilerin belirli bir algoritmayı takip ederek soruyu çözmesini gerektirecek şekildedir. Konu sonlarında ve sınavlarda ise bu sorular genellikle çoktan seçmeli soru tipinde sorulmaktadır (Hartman \& Lin, 2011). Birçok durumda öğrencilerin algoritmik sorulara verdikleri sayısal yanıtlar, onların doğru anlamalarının işareti olarak kabul edilmekte ve kavramsal anlama eksikliklerini saklamalarına imkan vermektedir (Nurrenbern \& Pickering, 1987; Phelps, 1996). Yapılan pek çok çalışma bu duruma dikkat çekmekte ve kimyada algoritmik problemleri çözmeye odaklanmanın, öğrencilerin kavramsal anlamalarını sağlamadığına vurgu yapmaktadır (Boujaoude \& Barakat, 2003; Gultepe, Yalcin Celik \& Kilic, 2013; Sözbilir, Pınarbaşı \& Canpolat 2010). Problem çözmeyle ilgili çalışmalar incelendiğinde; çoğunlukla öğrencilerin algoritmik problem çözücüler mi yoksa kavramsal problem çözücüler mi olduklarını belirlemeye yönelindiği ve bunun içinde kavramsal ve algoritmik soruları içeren kağıt kalem testi kullanıldığı görülmektedir. Böylece öğrencilerin algoritmik ve kavramsal soruları çözmedeki performansları değerlendirilmektedir (Coştu, 2010; Papaphotis, \& Tsaparlis, 2008; Yılmaz, Tuncer \& Alp, 2007). Bu çalışmaların çoğunda algoritmik sorular, çoktan seçmeli soru tipinde sorulmaktadır. Öğrencilerin, soruyu çözme sırasındaki düşünme ve kavramları anlama biçimlerine bakılmaksızın, doğru seçeneği işaretlemeleri ise soruyu doğru çözdükleri anlamı taşımaktadır. Her ne kadar bu çalışmalarda kavramsal sorular ile öğrencilerin düşünme biçimleri ortaya çıkarılmaya çalışılsa da algoritmik sorulardaki performans yüksekliği, doğru seçeneği işaretlemekle ölçülmektedir. Dolayısıyla öğrencilerin algoritmik sorulardaki kavramlara yükledikleri anlam ve bunları düşünme biçimleri bilinmemektedir. Bu açıklamalara dayanarak bu çalışmada; öğrencilerin algoritmik soruları çözerken neler düşündükleri, soruda 
geçen kavramlara yükledikleri anlam ve hangi kavramlar arasında nasıl ilişkiler kurdukları incelenmeye çalışılmıştır. Bu amaçla yukarıda bahsi geçen çalışmalardan farklı olarak sorular, çoktan seçmeli kalem-kağıt testi değil açık uçlu sorular şeklinde sorulmuştur. Öğrencilerin verilen algoritmik soruları nasıl çözdükleri, sesli düşünme protokolü kullanılarak incelenmiştir.

Sesli düşünme protokolü, sesli düşünme yöntemi kullanılırken elde edilen verileri içerir. Sesli düşünme yöntemi, katılımcıların bir problemi çözerken veya bir görevi tamamlarken düşüncelerini sözlü olarak ifade etmelerini ya da sesli düşünmeleri için sorular sormayı ve bu yolla ortaya çıkan sözlü protokolleri analiz etmeyi gerektirir (Overton, Potter \& Leng, 2013; van Someren, Barnard \& Sandberg, 1994, s. 1). Bu yöntem, araştırmalarda katılımcıların yerine getirdikleri görevin ürününden ziyade görevi tamamlama sürecini gözlemeyi ve analiz etmeyi sağlar. Sesli düşünme yöntemi, psikoloji ve eğitim alanlarında bilişsel süreçler üzerine yapılan araştırmalarda kullanılmaktadır (van Someren vd., 1994, s.2). Bu bağlamda kimya eğitiminde problem çözümünü konu edinen pek çok araştırmada da kullanıldığı görülmektedir (Bowen, 1994; Overton vd., 2013; Randles \& Overton, 2015; Staver \& Lumpe, 2006). Sesli düşünme yöntemiyle katılımcıların problem çözme süreçlerinin incelenmesi; katılımcıların düşünme süreçlerinin incelenmesine fırsat sunar. Böylece katılımcının elde ettiği sonuca nasıl ulaştığı, ne düşündüğü, katılımcı için problemle ilgili neyin zor neyin kolay olduğu, katılımcının çelişkileri nasıl çözdüğü belirlenebilir. Problem çözümü incelemelerinde yalnızca sonuca odaklanmanın, sözü edilen bu verilere ulaştırmayacağı da dikkate alınmalıdır (van Someren vd., 1994, s.1).

Sesli düşünme yönteminin alanyazında farklı şekilde kullanımları söz konusudur. Bu kullanımlardan iki tanesi eş zamanlı ve geçmişe dönük olarak sözlü ifade şeklindedir (Chandrasegaran, Treagust, Waldrip \& Chandrasegaran, 2009; Kuusela \& Paul, 2000). Eş zamanlı sözlü ifade etmede; katılımcılar bir problemin çözümünü yaparken kendi düşünme süreçlerini açık bir şekilde ifade ederler. Veriler, karar verme süreci sırasında toplanır. Burada hem problem çözme görevi yerine getirilir hem de sözlü ifadeler üretilir. Dolayısıyla katılımcılar bu iki görevi aynı zamanda yerine getirirler. Katılımcıların yerine getirdikleri bu iki görev ise birbirleriyle son derece ilişkilidir (Chandrasegaran vd., 2009; Randles \& Overton, 2015). Eş zamanlı sözlü ifade etme, katılımcıların karar verme adımlarının daha iyi anlaşılmasına olanak sağlamaktadır (Kuusela \& Paul, 2000). Geçmişe dönük sözlü ifade etmede ise katılımcılara daha önce yerine getirdikleri problem çözümündeki düşünme süreçleriyle ilgili sorular sorulur (Chandrasegaran vd., 2009). Böylece katılımcıların daha önce yerine getirdikleri görevle ilgili düşünme süreçlerini yansıtmaları sağlanır (Kuusela \& Paul, 2000). Bu iş, bilgiler katılımcıların zihinlerinde tazeyken yapılır. Burada araştırmacı, problem çözme sürecine ilişkin derinlemesine araştırma yapmak için sondalar kullanabilir. Geçmişe dönük sözlü ifade etmede karşılaşılacak eksikliklerin, katılımcıların yazılı çözümleriyle karşılaştııılarak en aza indirilebileceği önerilmektedir (Chandrasegaran vd., 2009). Bu çalışmada öğrencilerin problem çözme sırasındaki düşüncelerini açığa vurmaları beklendiğinden eş zamanlı sözlü ifade etme kullanılmıştır. Bu kullanımda güvenirliği ve olası eksiklikleri tamamlamak amacıyla öğrencilerin yazılı çözüm kağıtları da incelenmiştir.

Çalışmada öğrencilere yöneltilen sorular, kimyasal denge konusuyla ilgilidir. Kimyasal denge, kimyanın önemli konuları arasında yer almakla birlikte öğrencilerde kavram yanılgılarının sıklıkla görüldüğü bir konudur (Kousathana \& Tsaparlis, 2002; Özmen, 2008; Quilez-Pardo \& Solaz-Portoles, 1995). Kimyasal denge konusuyla ilgili yapılan çalışmalar incelendiğinde; çalışmalarda çoğunlukla öğrencilerdeki konuyla ilgili kavram yanılgılarının, öğrencilerin konuya ilişkin akademik başarılarının ya da kavramsal anlamalarının belirlendiği görülmektedir.

Kavram yanılgılarını belirlemeye yönelen çalışmalar, öğrencilerdeki kavram yanılgılarını açığa çıkarmak için çeşitli yöntemler kullanmaktadır. Bu yöntemlerden en çok kullanılanlarının; 
iki veya üç aşamalı kavram testleri (Akkus, Kadayifci \& Atasoy, 2011; Tunç, Akçam \& Dökme, 2011), açık uçlu kavramsal veya algoritmik soruları içeren kağıt-kalem performansına dayalı testler (Sözbilir vd., 2010) ve kelime ilişkilendirme testleri (Cachapuz \& Maskill, 1989) olduğu söylenebilir. Öğrencilerin konuyla ilgili başarılarını belirlemeye yönelen çalışmalarda ise kavramsal, algoritmik veya grafik soruların kullanıldığı ve bu soruların da çoğunlukla çoktan seçmeli soru tipinde sorulduğu görülmektedir (Bilgin \& Geban, 2006; Şimşek, Doymuş, Doğan \& Karaçöp, 2009). Bu soruların cevaplarının doğru işaretlenmesi de öğrencilerin konuyu öğrendiklerinin yada akademik olarak başarılarının işareti olarak kabul edilmektedir.

Yukarıda verilenler dikkate alındığında kimyasal dengeyle ilgili çalışmalarda algoritmik soruların sıklıkla kullanıldığı görülmektedir. Bu kullanımların çoğunluğunda ise değerlendirmenin seçenek işaretlemeye dayalı olarak yapıldığı görülmektedir. Bu çalışmada bahsi geçen çalışmalardan farklı olarak kimyasal denge konusuna ilişkin algoritmik soruları öğrencilerin nasıl çözdükleri, sesli düşünme yoluyla açık uçlu soruların kullanılması suretiyle incelenmiştir. Böylece problem çözmede sonuçtan ziyade sürece odaklanmak hedeflenmiştir. Öğrencilerin algoritmik soruları çözerkenki düşüncelerini inceleme yoluyla; öğrencilerin konuyla ilgili anlayışları açığa çıkarılmaya çalışılmıştır. Buradan yola çıkılarak çalışmada aşağıda verilen sorunun yanıtı aranmaya çalışı ımışır:

11. sınıf öğrencilerinin kimyasal denge konusuyla ilgili algoritmik soruları çözme sürecinde; kavramlar ve kavramlar arası ilişkileri tanımlama, değişkenleri/verileri yorumlama, formül/bağıntı ve algoritma kullanma durumları ve bunları yaparkenki düşünceleri nelerdir?

\section{YÖNTEM}

Bu araştırma, nitel araştırma yöntemlerinden durum çalışmasıdır. Nitel araştırma, bir amaç doğrultusunda örneklem alınmasını, açık uçlu sorularla veri toplanmasını, dokümanların veya görsellerin analizini ve bulguların kişisel olarak yorumlanmasını içeren bir araştırma modelidir (Creswell, 2013-a, s. 12). Nitel araştırmalarda, katılımcının/katılımcıların bakış açısıyla olguların veya olayların mantığı anlaşılmaya çalışılır (Merriam, 2002, s.6). Durum çalışması ise belli bir zaman içerisindeki çoklu sınırlandırılmış sistemler hakkında çoklu bilgi kaynakları (gözlemler, mülakatlar, dokümanlar, raporlar vb.) aracılığıyla derinlemesine bilgi toplandığı, durumların ve durumlara bağı temaların ortaya konulduğu nitel bir araştırma yaklaşımıdır (Creswell, 2013-b, s. 97). Durum çalışmaları ile araştırmacı; bir olguyu, olayı, eylemi, süreci veya kişi, grup, kurum veya topluluk gibi sosyal birimleri derinlemesine analiz eder (Creswell, 2013a, s. 14; Merriam, 2002, s. 8).

\section{1. Çalışma Grubu}

Araştırmanın çalışma grubu, amaçlı örnekleme yöntemi kullanılarak belirlenmiştir. Amaçlı örnekleme yönteminde örneklem, rastgele değil özel bir amaca yönelik olarak seçilir (Balcı, 2010, s. 98). Bu bağlamda araştırmanın çalışma grubu; Türkiye'nin iç Anadolu Bölgesi'nde yer alan bir ildeki ortaokuldan sonra sınavla ve bulunduğu ilde kendi kategorisinde (Anadolu Lisesi) en yüksek puanla öğrenci alan bir okulun 11. sınıf öğrencileri arasından seçilmiştir. Okul seçiminin gerekçesi bu okul türünün, Türkiye'de sınavla öğrenci alan ve en yüksek kalitede eğitim verdiği kabul edilen okul türlerinden biri olmasıdır (Eğitim Reformu Girişimi, 2014). Öğrencilerin 11. sınıf öğrencilerinden seçilmesinin nedeni ise; çalışmaya konu olan kimyasal denge konusunun 11. sınıf kimya dersi kapsamında öğretilmesidir.

Çalışmaya 6 öğrenci katılmıştır. Bu öğrencilerin seçiminde ölçüt olarak kimya başarı düzeyleri alınmıştır. Bu tür örneklem seçme yöntemi, amaçlı örneklem yönteminden ölçüt örneklem olarak ifade edilir (Teddlie \& Yu, 2007). Öğrencilerin kimya başarı düzeyleri, okulun kimya öğretmeninin önerileri ve öğrencilerin bir önceki döneme ait kimya dersi not 
ortalamaları doğrultusunda belirlenmiştir. Bunun için belirtilen okulda öğrenim gören tüm 11. sınıf öğrencilerinin not ortalamalarına bakılmış ve bunların 70-100 aralığında değiştiği belirlenmiştir. Buna göre not ortalamaları 100-90 aralığında olanların başarı düzeyi yüksek, 9080 aralığında olanların orta ve 80-70 aralığında olanların düşük olarak üç grup halinde nitelendirilmiştir. Ardından belirlenen bu üç gruptan ikişer öğrenci, okulun kimya öğretmeninin önerileri doğrultusunda ve öğrencilerin gönüllü katılımları dikkate alınarak seçilmiştir. Araştırmaya katılan bu altı öğrencinin isimleri çalışmada kodlanarak Ö1, Ö2... şeklinde verilmiştir.

Tablo 1

Çalışma Grubuyla Ilgili Özellikler

\begin{tabular}{clcl}
\hline Öğrenci & Cinsiyet & Not ortalaması* $^{*}$ & Başarı değerlendirmesi \\
\hline Ö1 & Kız & 97 & Başarılı düzeyi yüksek \\
Ö2 & Erkek & 92 & Başarı düzeyi yüksek \\
Ö3 & Kız & 85 & Başarı düzeyi orta \\
Ö4 & Kız & 82 & Başarı düzeyi orta \\
Ö5 & Erkek & 70 & Başarı düzeyi düşük \\
Ö6 & Kız & 75 & Başarı düzeyi düşük \\
\hline
\end{tabular}

*Not ortalamaları 100 üzerindendir.

\subsection{Veri Toplama Süreci}

Araştırmanın verileri, 2014-2015 eğitim öğretim yılının ikinci yarıyılında, 11. sınıf kimya dersinde kimyasal denge konusunun işlenmesinden dört hafta sonra toplanmıştır. Verilerin toplanması sürecinde öncelikle araştırmaya katılan öğrencilerle birlikte görüşme için uygun bir zaman belirlenmiş ve belirlenen zamanda öğrencilerin okullarına gidilerek görüşmeler ayrı ayrı gerçekleştirilmiştir. Görüşmelere sesli düşünme yönergesinin (Ek-1) öğrencilere verilmesiyle başlanmıştır. Sesli düşünme yönergesi, alanyazında yapılan çalışmalardan faydalanılarak hazırlanmış ve Türkçe eğitimi alanında çalışan bir uzmanın görüşleri alınarak son şekli verilmiştir. Çalışmada öğrencilerin bu yönergeyi okumaları sağlanmış ve kendilerinden istenileni anladıklarından emin olunduktan sonra algoritmik soru formu verilmiştir. Algoritmik soru formunda yer alan sorular, alanyazın taranarak hazırlanmış ve kimya ve kimya eğitimi alanlarında çalışan birer uzman ile Anadolu Lisesi'nde görev yapan (mesleki deneyimleri 15 ve 18 yıl) iki kimya öğretmeninin görüşleri alınarak son şekli verilmiştir.

Öğrencilerden algoritmik soru formunda yer alan soruları, sesli düşünme yönergesinde belirtilen hususlara dikkat ederek çözmeleri istenmiştir. Öğrenciler çözümlerini kağıt, kalem ve hesap makinesi kullanarak yapmışlardır. Öğrencilerin soruları çözme süreleri 20 ile 45 dakika arasında değişmiştir. Görüşmeler, ses kayıt cihazı kullanılarak kayıt altına alınmıştır.

\subsection{Verilerin Analizi}

Araştırmanın verileri, öğrencilerin ses kayıtları ve soruların çözümlerini yaptıkları kâğıtlardır. Verilerin analizi sürecinde öncelikle öğrencilerin ses kayıtları transkripsiyon yöntemi ile yazılı hale getirilmiştir. Bu süreç, her bir öğrencinin soruların çözümlerini yazdıkları kâğıtlarla birlikte yürütülmüş ve ses kayıtları ile kâğıda yazılan çözümler birleştirilerek her bir öğrenciye ait soru çözüm dokümanı (protokol) elde edilmiştir. Bu dokümanların doğruluğu tekrarla kontrol edilmiştir. Araştırmanın kavramsal yapısı ve analizine temel oluşturacak temalar önceden belirlendiği için öğrencilerin kimyasal denge konusuyla ilgili algoritmik soruları çözme biçimlerini ve düşüncelerini ortaya koyacak veriler, betimsel analiz tekniği ile çözümlenmiştir. Araştırmanın verileri eğitimde ölçme ve değerlendirme alanında çalışan iki uzmanın görüşleri de alınarak; kavramları ve kavramlar arası ilişkileri tanımlama, problemde yer alan değişkenleri/verileri yorumlama, formül/bağıntı kullanma ve algoritma kullanma olmak üzere dört tema altında incelenmiş ve yorumlanmıştır. Bu temalar, algoritmik bir sorunun çözüm 
sürecindeki aşamalar dikkate alınarak belirlenmiştir (Altun, 2000; Altun \& Arslan, 2006). Yapılan betimsel analizin güvenirliğini sağlamak için verilerin temalar altında incelenmesi, araştırmacı ve kimya eğitimi alanında bir başka uzman tarafından ayrı ayrı olarak yapılmıştır. Bu inceleme; her bir öğrenciden elde edilen protokolün incelenmesini ifade etmektedir. Protokollerde her bir satır numaralı bir şekilde yer almaktadır. Bir protokol incelenirken bu satırlar, belirli kısımlara ayrılmış (1. ve 8 . satırlar gibi) ve bu kısımlar yukarıda verilen temalardan hangisinin altında inceleneceğine göre değerlendirmeye tabi tutulmuştur (van Someren vd., 1994, s. 142-152). Sonra iki değerlendirme arasındaki uyuma bakılmıştır. Bu işlemde Kodlayıcılar Arası Güvenirlik= Görüş Birliği/(Görüş Birliği+Görüş Ayrılı̆̆ı) formülünden (Miles \& Huberman, 1994) yararlanılmış ve kodlayıcılar arası güvenirlik 0,96 olarak hesaplanmıştır. Bu oran, güvenirlik için yeterli kabul edilmiştir (Miles \& Huberman, 1994).

\section{BULGULAR ve YORUMLAR}

Araştırmanın bulguları, öğrencilerin kimyasal denge problemlerini çözerkenki düşüncelerinin her bir soru için temalar çerçevesinde sınıflandııılması ve doğrudan aktarımlara da yer verilmesi yoluyla sunulmuştur. Bu aktarımlarda öğrenci ile araştırmacı diyaloglarında kullanılan Ö1, Ö2 ... öğrencileri; A, araştırmacıyı ifade etmektedir.

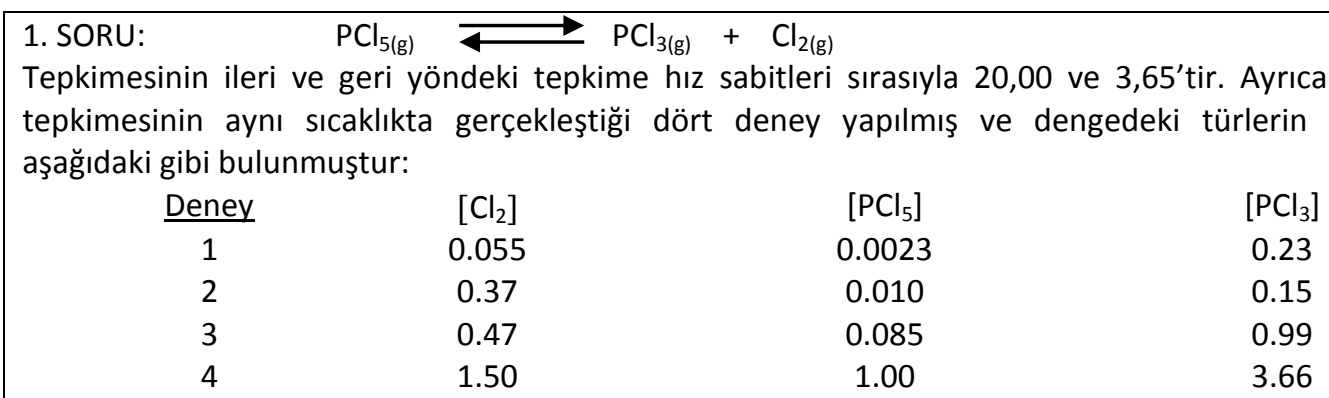

Yukarıda verilen tepkimenin denge sabitini, $\mathrm{K}_{\mathrm{c}}$ hesaplayınız.

\section{Kavramları ve kavramlar arası ilişkileri tanımlama}

Birinci soruda denge, denge sabiti, ileri yönde tepkime hız sabiti, geri yönde tepkime hız sabiti ve derişim kavramları yer almaktadır. Tepkime hızı kavramı da bu kavramlarla bağlantısı olan bir kavramdır. Bu nedenle bu sorunun çözümünde öğrencilerin bu kavramlarla ilgili temel bir anlayışa sahip olmaları gerekmektedir. Sorunun çözümünü yaparken, tepkime hız sabiti kavramını yalnızca bir öğrenci (Ö3) açıklamıştır. Ö3’e ait ifade örneği aşağıdadır:

"Tepkime hız sabiti tepkimenin hızlarıyla ilgili bir değer. Bir tepkimede girenlerdeki mesela burada $\mathrm{PCl}_{5}$ gibi, onu yazarken k sabiti var (Ö3)."

Yukarıdaki açıklamadan öğrencinin kavramla ilgili doğru bilgilere sahip olduğu ancak bunu ifade ederken zorlandığı ve tatmin edici açıklamalar yapamadığı söylenebilir.

Başka bir öğrencinin (Ö1) ise denge kavramını hatalı bir şekilde aşağıdaki gibi açıkladığı görülmüştür:

"Ö1: Bir dakika düşüneyim.. Eşit olduğu zaman ( $k_{i}$ ve $k_{g}{ }^{\prime} y i$ kastederek) dengede oluyordu. $k_{i}$ ve $k_{g}$ birbirine eşit olması lazım."

Ö1'in açıklamasındaki hatanın nedeni; ders kitaplarında geçen "Denge; ileri ve geri yöndeki tepkime hızlarının birbirine eşit olmasıdır." şeklindeki tanımlamada yer alan tepkime hızlarının eşit olması ifadesi, hız sabitlerinin eşit olması şeklinde düşünülmesi yani tepkime hızı ile tepkime hız sabiti kavramlarının birbirine karıştırılması olabilir. Bu karmaşaya iki kavramın ne olduğunun tam olarak anlaşılmamasının neden olduğu söylenebilir. Bu sorudaki kavramları ve kavramlar arası ilişkilere ilişkin diğer öğrencilerin açıklama getirmedikleri görülmüştür. 


\section{Problemde yer alan değişkenleri/verileri yorumlama}

Öğrencilerin tamamının birinci soruda verilen verileri yorumlamakta güçlük çektikleri görülmüştür. Öğrenciler özellikle tepkime hız sabiti ile ilgili verilen sayısal verileri nasıl kullanacaklarını ve bu verilerin ne anlama geldiğini bilememişlerdir. Konuya ilişkin örnek öğrenci ifadeleri aşağıda sunulmuştur:

"ileri ve geri tepkime hız sabitlerini vererek denge sabitinin sorulduğu bir soruyla daha önce karşılaşmadım. (Ö2)."

"Soruda ileri ve geri hız sabitlerini vermiş 20 ve 3,65 ama bunları nereye yazacağım (Ö3)."

"Ama burada hız sabitlerini nasıl kullanacağım bilmiyorum (Ö5)."

"Hız sabitlerini ayrıca vermeleri değişik. Soruda hız sabitlerini verdiğine göre kullanmamız gerekiyor. Ama nerede kullanacağımı bilmiyorum (Ö6)."

Hız sabitleri ile ilgili verileri bir öğrenci (Ö1) ise hatalı bir şekilde şöyle yorumlamıştır:

"ileri yöndeki hız sabiti daha büyük, $k_{i}>k_{g}$ o zaman dengede değil zaten. Dengeye gitmesi için ürünlere kayması lazım. O zaman ürünlerden oluşacak (Ö1)."

Ö1'in hatalı yorumunun nedeni yukarıda da bahsedildiği gibi büyük olasılıkla tepkime hızı ile tepkime hız sabiti kavramlarını birbirine karıştırmış olması olabilir. Bu nedenle de soruda dengede olan sistemi, dengede değilmiş gibi düşünmüş ve sistemin dengeye nasıl ulaşacağı konusunda yorum yapmıştır. Öte yandan soruda verilen dört deneye ait denge derişimleri de öğrenciler tarafından doğru bir şekilde yorumlanamamıştır. Buna ilişkin örnek öğrenci ifadeleri aşağıda sunulmuştur:

"Deneysel verileri vermiş. Bunu kullanabiliriz. Değerlerden biri sabit, diğeri katları şeklinde artıyor ya da azalıyor olmalı. Böyle soruyla karşılaştım. Ama burada sabit yok, katları şeklinde de değil. Bunu nasıl yapacağımı bilemiyorum (Ö4)."

"Ö3: Biz hızda bir şey öğrenmiştik; bu şekilde 1., 2., 3. ve 4. diye yapılan deneylerde kıyaslama yapıp, aralarındaki artışa göre bir bağıntı buluyorduk. Bende bu sorudaki deneyler arasında kıyaslama yapıp bağıntı kurmaya çalışacağım.

A: Bağıntıyı neye göre kuracaksın?

Ö3: Biz hızda şöyle bir şey yapmıştık; mesela 1 ile 2 sabittir ama 1 ile 3 orantılı olarak artıyor. Buna göre bir hiz denklemi yazılıyordu. (Soruda verilen tabloya bakarak) Ancak burada nasıl bir oran bulacağım? Sayılar uygun değil. Sabit değerler yok."

Yukarıda verilen öğrenci ifadelerinde göze çarpan en önemli yorumlama biçimi, verilerin aynı sıcaklıkta dört farklı deney için verilen denge derişimleri olarak değerlendirilmemiş olmasıdır. Öğrencilerin her bir deneyi ayrı ayrı değerlendirmek yerine birbirleriyle ilişki kurarak değerlendirmeye çalıştıkları görülmüştür. Bu değerlendirmeyi ise kimyasal tepkimelerde hız konusunda tepkenlerin ve ürünlerin derişimlerine ait deneysel verileri kullanarak tepkime hızına iliş̧in çıkarımda bulunma stratejisine dayandırmışlardır. Bu durum, öğrencilerin tepkime hızı ve denge konularını ayırmada ya da ilişkilendirmede karmaşa yaşadıklarına işaret etmektedir. Bunun yanında bir öğrenci (Ö1) ise her ne kadar 'tepkime hızı konusunda kullanılan deneysel veriler üzerinden deneyler arası kıyaslama yaparak hız bağıntısını bulma stratejisini' kullanmasa da tablodaki verileri yine deneyler arası kıyaslamaya tabi tutmuş ve tepkenlerdeki ve ürünlerdeki türlerin derişimlerinin artmasını anlamlandıramamış ve biri artarken diğerinin azalması gerektiği yorumunu yapmıştır. Bu duruma ilişkin Ö1'in ifadeleri şöyledir:

"Ö1: (Tabloya bakarak) Deneyde $\mathrm{Cl}_{2}$ derişimi giderek artmış, $\mathrm{PCl}_{5}$ derişimi de artmış. Burada bir dengesizlik var, $K_{c}^{\prime}$ yi nasıl hesaplayacağız. Biri artmış $\left(\mathrm{Cl}_{2}\right)$ diğeri azalmış $\left(\mathrm{PCl}_{3}\right)$, 
burada bir dengesizlik var, böyle denge mi olur? Çünkü ikisinin de artması ya da ikisinin de azalması gerekiyordu.

A: Neden böyle düşünüyorsun?

Ö1: Bir madde eklenirdi, sıcaklık artırılırdı veya basınçta değişiklik olurdu, böyle durumlarda ikisi de ya artardı yada azalırdı. Ama burada birisi $\mathrm{Cl}_{2}$ artmış, $\mathrm{PCl}_{3}$ azalmış, değişik."

Ö1'in konuyla ilgili düşünceleri incelendiğinde; tepkenler azalırken ürünlerin artması veya tam tersi tepkenler artarken ürünlerin azalması gerektiği düşüncesi doğrudur. Ancak burada hatalı olan; deneyler arası kıyaslamanın yapılması ve verilerin zaten dengedeki bir sistemdeki türlerin verileri değil de dengeye ulaşmak için meydana gelen derişim değişimlerini gösteren veriler olarak değerlendirilmesidir. Bu durum ise sorunun tam olarak anlaşılmadığına işaret etmektedir.

\section{Formül/bağıntı kullanma}

Bu sorunun çözümünde öğrencilerin $\mathrm{K}_{\mathrm{c}}=[\mathrm{U} r u ̈ n] /[G i r e n], \mathrm{K}_{\mathrm{c}}=\left[\mathrm{PCl}_{3}\right] \cdot\left[\mathrm{Cl}_{2}\right] /\left[\mathrm{PCl}_{5}\right], \mathrm{K}_{\mathrm{c}}=\mathrm{k}_{\mathrm{i}} / \mathrm{k}_{\mathrm{g}}$ ve $\mathrm{k}_{\mathrm{i}} / \mathrm{k}_{\mathrm{g}}$ formüllerini/bağıntılarını kullandıkları görülmüştür. Ancak verilen ilk iki formülün ne anlam ifade ettiğini bilmedikleri ve nasıl çıkarıldıklarıyla ilgili fikirlerinin olmadığı ya da nasıl çıkarıldığının derste gösterildiği ama öğrencilerin hatırlamadıkları belirlenmiştir. Bu formülleri kullanan öğrencilerin tamamı, formülü ezberlediklerini ifade etmişlerdir. Aşağıda konuyla ilgili örnek bir öğrenci ifadesi yer almaktadır.

" $K_{c}=\left[\mathrm{PCl}_{3}\right] \cdot\left[\mathrm{Cl}_{2}\right] /\left[\mathrm{PCl}_{5}\right]$ dengede bu şekilde yazıyorduk. Yani ürün bölü giren şeklinde yazıyorduk. Soruda böyle çözüyorduk (Ö5)."

Bir öğrenci (Ö6) ise formülün yazııı̧ını, hatalı bir şekilde aşağıdaki gibi yorumlamıştır:

“Ö6: Kc değerini ürün bölü girenden hesaplıyorduk.

A: Bunu neye göre belirledin?

Ö6: Soru tiplerinden. Burada tepkenler harcanıyor. O yüzden ürünlerden başlayıp girenlere doğru yazıyoruz. Ürünler payda, girenler paydada. Oluşanlar payda, harcananlar paydada (Ö6)."

Yukarıdaki ifadeler Ö6'nın, denge kavramı ile başlangıçta hem tepkenlerin hem de ürünlerin birlikte konulduğu sistemlerdeki denge durumlarını bilmediğini veya böyle sistemlerde dengeye ulaşmak için daima tepkenlerden harcanacağı fikrine sahip olduğunu düşündürmektedir.

Bu sorunun çözümünde kullanılan ve yukarıda verilen üçüncü ve dördüncü formülü ise birer öğrenci kullanmıştır. $K_{c}=k_{i} / k_{g}$ formülünü kullanan öğrenci (Ö1), bu formülü hatalı bir biçimde aşağıdaki gibi tekrar değiştirmiştir:

"Ö1: $K_{c}=k_{i} / k_{g}$ şeklinde yazayım. Bir dakika. Düşüneyim.. Eşit olduğu zaman dengede oluyordu. Birbirine eşit olması lazım. O zaman; $k_{c}=k_{i} / k_{g}=1$ olması lazım.

A: Neden 1 olması gerekiyor?

Ö1: Dengede olması için oranları 1 olması gerekiyor diye biliyorum."

Ö1 formülü değiştirdiğinde $\mathrm{k}_{\mathrm{i}} / \mathrm{k}_{\mathrm{g}}$ oranı $\mathrm{K}_{c}^{\prime}$ 'ye değil 1'e eşit olmuştur. Burada büyük olasılıkla ders kitaplarında geçen "Denge; ileri ve geri yöndeki tepkime hızlarının birbirine eşit olmasıdır." şeklindeki tanımlamadaki hız ifadesi, hız sabitlerinin eşit olması şeklinde düşünülmüş ve $k_{i}=k_{g}$ olduğunda denge kurulacağı kanaatine varılmış ve bu nedenle $k_{\mathrm{i}} / \mathrm{k}_{\mathrm{g}}$ oranının 1 olması gerektiği sonucuna ulaşıımış olabilir. 
Yine bu sorunun çözümünde kullanılan ve yukarıda verilen formüllerden $\mathrm{k}_{\mathrm{i}} / \mathrm{k}_{\mathrm{g}}$ oranını bir öğrenci (Ö4) kullanmış ancak bu oranının hangi niceliği ifade ettiğini bilemediğini aşağıdaki gibi ifade etmiştir:

" $k_{i} / k_{g}=20 / 3,65=5,4$ çıktı. Ama bu ne ifade ediyor ki. Neye eşit?"

Bu soruda bir öğrenci (Ö2) ise ileri ve geri tepkime hızlarıyla ilgili formülü hatırlayamadığı için soruyu çözemediğini ifade etmiştir. Öğrenciye ait ifadeler şöyledir:

"Hız sabitlerini vermiş, bunlarla ilgili dört deney yapmış, $\mathrm{Cl}_{2}$ artınca $\mathrm{PCl}_{5}$ de artmış. Ters giden bir şey yok gibi. Ama denge sabitini hesaplayamadım, hız sabitlerini kullanarak nasıl hesaplıyorduk, hatırlayamadım. Formülü hatırlayamadığım için çözemiyorum. Hatırlasam çözerim (Ö2)."

Ö2'ye ait yukarıda verilen ifadeler; kimyasal denge kavramının ve $K_{c}$ bağıntısına nasıl ulaşıldığının Ö2 tarafından anlaşılmayışına ve formülün anlamlandııılmadan ezberlendiğine işaret etmektedir. Aslında denge sabitini veren bağıntının, denge kavramından yola çıkılarak kolaylıkla bulunabilmesi beklenebilir. Burada öğrencinin denge kavramıyla ilgili derinlemesine bir anlayış geliştiremediği ya da bildiklerini matematiksel bir eşitliğe dönüştüremediği başka bir ifadeyle bilgiyi dönüştüremediği söylenebilir.

\section{Algoritma kullanma}

Bu sorunun çözümünde $\mathrm{K}_{\mathrm{c}}=\mathrm{k}_{\mathrm{i}} / \mathrm{k}_{\mathrm{g}}$ ya da $\mathrm{K}_{\mathrm{c}}=\left[\mathrm{PCl}_{3}\right] .\left[\mathrm{Cl}_{2}\right] /\left[\mathrm{PCl}_{5}\right]$ bağıntısında verileri yerine koyarak $\mathrm{K}_{c}^{\prime} \mathrm{yi}$ hesaplamayı içeren tek aşamalı bir algoritmanın kullanılması gerekir. Ancak öğrencilerden bazıları soruyu çözerken; kimyasal tepkimelerde hız konusuyla ilgili bazı soruların çözümünde kullandıkları algoritmayı, bu sorunun çözümünde de kullanmayı denedikleri görülmüştür. Bu duruma ilişkin örnek öğrenci ifadeleri şöyledir:

"Biz hızda şöyle bir şey yapmıştık; mesela 1 ile 2 sabittir ama 1 ile 3 orantılı olarak artıyor. Buna göre bir hız denklemi yazılıyordu. (Soruda verilen tabloya bakarak) Ancak burada nasıl bir oran bulacağım? Sayılar uygun değil. Sabit değerler yok. Böyle bir soru ilk defa görüyorum, hız sabitiyle ikisini birleştirip sormuş. Sanırım soruyu çözemeyeceğim (Ö5)."

"Ö6: Illk önce deneylerde aynı olanı bulurum.

A: Aynı olanı derken neyi kastediyorsun?

Ö6: Dengenin değiştiği ya da ortak olduğu yerlere bakarım. Ama böyle değerler yok."

“Ö5: Burada önce sabit olanı seçiyorduk.

A: Hangi yönden sabit olanı seçiyorsun?

Ö5: Biz önce sabit olanı seçiyorduk. Şöyle $\mathrm{Cl}_{2}, \mathrm{PCl}_{5}, \mathrm{PCl}_{3}$ bunlardan biri sabit oluyordu ve diğerlerindeki artışa bakıyorduk. Ancak bu uymuyor. Sanırım bu yolla çözemeyeceğim."

Konuya ilişkin yukarıda verilen öğrenci ifadelerinde dikkat çeken durum; öğrencilerin sorudaki deneysel veri setinden yola çıkarak kimyasal tepkimelerde hız konusunda tepkenlerin ve ürünlerin derişimlerine ait deneysel verileri kullanarak tepkime hızına ilişkin çıkarımda bulunma stratejisini uygulamaya çalıştıkları ancak bu stratejinin uygulanamayacağını fark edince soruyu çözmekten $(0 ̈ 5$, Ö2) ya da bu yolla çözmekten $(0 ̈ 4,0 ̈ 6)$ vazgeçmeleridir. Buna ilişkin örnek öğrenci ifadeleri ise şöyledir:

"Ö4: Formülü yazarım, $K_{c}=\left[\mathrm{PCl}_{3}\right] \cdot\left[\mathrm{Cl}_{2}\right] /\left[\mathrm{PCl}_{5}\right]$. Denge problemlerinde ürün bölü giren şeklinde yazıyorduk. Acaba burada tablodan bir değer mi seçip koysam. Böyle bir soru dengede hiç çözmedim. Hızda çözmüştüm ama dengede çözmedim. Denge sabitinin verilmediği bir soru hiç çözmedim. Ne yapmam gerektiğinin farkında değilim." 
"Ö6: $K_{c}=[\ddot{r} r u ̈ n] /[G i r e n]$ formülünden yerine yazarım, $K c=0,23.0,055 / 0,0023=5,5$. Ancak çözümden emin değilim."

Bu soruyu denge sabiti formülünü yazma-verileri yerine koyma-işlem yapmayı içeren basit algoritmayı uygulayarak çözen bir başka öğrenci (Ö1), soruyu doğru bir şekilde üstelik birkaç farklı yolla çözmeyi başarmış ancak bulduğu sonuçların birebir aynı çıkmadığını görünce $(5,50 ; 5,55 ; 5,49)$ sıcaklığın değişmiş olabileceğini düşünmüştür.

“Ö1: 1. Deneyde $[(0,055) \cdot(0,23)] /(0,0023)=5,50$

$$
\begin{aligned}
& \text { 2. deney }[(0,37) \cdot(0,15)] /(0,010)=5,55 \quad \text { Farklı çıkıyor. 4. yü deneyeyim. } \\
& \text { 4. deney }[(3,66) \cdot(1,50)] /(1,00)=5,49
\end{aligned}
$$

Denge sabiti her seferinde farkı çıkıyor. Ne yapacağımı bilemiyorum. O zaman sıcaklık değissiyor. Denge sabiti sıcaklıkla değişir sadece. Çözemedim."

Ö1'in çözümü incelendiğinde; Ö1'in denge sabitinin sıcaklıkla değiştiğini bilmekle birlikte buradaki durumun deneysel çalışmalardaki rasgele hatalardan kaynaklanabileceğinin farkında olmadığı söylenebilir. Bundan dolayı Ö1 soruyu, farkı formülün kullanıldığı aynı algoritmayla çözmüş ancak bu sefer de formülü hatalı bir şekilde değiştirerek soruyu aşağıdaki gibi yanlış çözmüştür:

"Ö1: Bir de hız sabitlerini vermiş. ileri yöndeki hız sabiti 20,00 geri yöndeki 3,65 ise o zaman;

$$
K_{c}=k_{i} / k_{g}=20,00 / 3,65=5,47
$$

Bir dakika eşit olduğu zaman dengede oluyordu. ileri hız sabiti fazla, o zaman tekime sağa doğru ilerleyecek girenler azalacak ürünler artacaktır. Birbirine eşit olması lazım.

$(20-x) /(3,65+2 x)=K_{c}=1$ olması lazım. 3,65+2x $=20-x=16,35^{\prime \prime}$

Son olarak bu soruyla ilgili bir öğrenci (Ö3), sorunun çözümü için herhangi bir algoritma önermemiş ve kullanmamıştır.

2. SORU: $1 \mathrm{~mol} \mathrm{H}_{2(\mathrm{~g})}, 1 \mathrm{~mol} \mathrm{I}_{2(\mathrm{~g})}$ ve $2 \mathrm{~mol} \mathrm{HI}_{(\mathrm{g})}, 10,0$ L'lik bir tepkime kabında $458{ }^{\circ} \mathrm{C}^{\prime}$ da karıştırılıyor. Bu sıcaklıkta;

tepkimesinin denge sabiti 50,3'tür.

$$
\mathrm{H}_{2(\mathrm{~g})}+\mathrm{I}_{2(\mathrm{~g})} \rightleftarrows 2 \mathrm{HI}_{(\mathrm{g})}
$$

Yukarıda verilenlere göre tepkime karışımı dengeye ulaştığında, kapta bulunan türlerin derişimlerini hesaplayınız.

\section{Kavramları ve kavramlar arası ilişkileri tanımlama}

İkinci soruda denge, denge sabiti ve derişim kavramları yer almaktadır. Bu sorunun çözümünde kullanılacak bir başka kavram tepkime oranı, Q'dur. Bu nedenle bu sorunun çözümünde öğrencilerin adı geçen kavramlarla ilgili temel bir anlayışa sahip olmaları gerekmektedir. Bu soruya ilişkin çözümler incelendiğinde; derişim (Ö1), kimyasal denge (Ö5, Ö3), denge sabiti (Ö3) ve $K_{c}$ ile $Q$ arasındaki ilişkinin (Ö2) açıklandığı görülmüştür. Yapılan açıklamalar incelendiğinde; derişim ve $\mathrm{K}_{\mathrm{c}}$ ile $\mathrm{Q}$ arasındaki ilişkinin doğru bir şekilde açıklandığı belirlenmiştir. Bu açıklamalara ilişkin örnek ifadeler şöyledir:

"Hacim 10 L olduğu için derişimi bulmak için mol sayılarını 10'a bölerim. Birim hacimdeki madde miktarı derişimi verir (Ö1)."

"Q'yu karşılaştırmak için kullanıyoruz. Q, Kc'den daha büyükse veya küçükse ileri yönde veya geri yönde gibi. Yani Q'yu tepkimenin ne yöne gideceğini bulmak için kullanırız (Ö2)."

Kimyasal denge kavramına ilişkin açıklamaya bakıldığında ise açıklamanın ilgisiz bir açıklama olduğu görülmektedir. Açıklamayla ilgili öğrenci ifadeleri aşağıda yer almaktadır: 
"Ö5: Kimyasal denge bir maddeyi ayrıştırmak istediğimiz zaman, 1. sorudaki örnekte olduğu gibi, denge gerekiyor diye düşünüyorum.

A: Neden denge gerekiyor?

Ö5: Ayrıştırmak için. Denge olmazsa ayrışmada olmaz."

Yukarıdaki açıklama ayrışma tepkimesinin gerçekleştiği bir sistemde, denge durumu olmadan ayrışmanın olamayacağı gibi bir hatayı da içermektedir. Aynı açıklamayı yapan öğrencinin (Ö5), denge sabitinin ne olduğu sorulduğunda denge sabiti üzerinde düşünmediğini belirterek herhangi bir açıklama yapamamış olması da konunun kavramsal seviyede anlaşılamadığını düşündürmektedir.

Başka bir öğrenci (Ö3) ise denge ve denge sabiti kavramlarını açıklamaya çalışmış ancak eksik bir şekilde şöyle ifade edebilmiştir:

"Denge sabiti, dengeye geldiği anda oluşan değer. Ileri tepkimenin geri tepkimeye eşit olduğu (Ö3)."

Ö3'ün açıklamasındaki bu eksiklik, kavramsal bilgi eksikliğinden kaynaklanmış olabileceği gibi düşünceleri ifade etmede ya da feni konuşmada yaşanan güçlükten de kaynaklanmış olabilir.

\section{Problemde yer alan değişkenleri/verileri yorumlama}

Bu soruda yer alan tüm değişkenler öğrenciler tarafından doğru bir şekilde anlaşıımış ve yorumlanmıştır. Öğrencilerin soru çözümleri incelendiğinde her ne kadar çözüm aşamalarında yanlışlıklar bulunsa da değişkenlere/verilere yükledikleri anlamların doğru olduğu görülmüştür. Konuyla ilgili örnek öğrenci ifadesi aşağıda sunulmuştur:

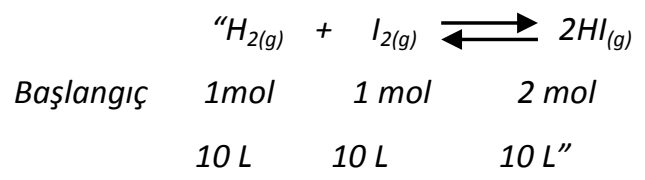

Mol sayılarını altlarına yazıyorum. Bunlar başlangıçtaki mol sayıları. Hacim 10 L olduğu için molariteyi bulmak için mol sayılarını 10'a bölüyorum (Ö2)."

Yalnızca bir öğrenci (Ö4) başlangıç mol sayılarının yalnızca tepkenlerde olabileceğini, ürünlerde olamayacağını düşünmüş, tereddüte düşmüş ve bunu şu şekilde ifade etmiştir:

$$
\begin{array}{cccc} 
& \text { " } \mathrm{H}_{2(g)}+I_{2(g)} \rightleftarrows 2 \mathrm{H}_{(g)} \\
\text { Başlangıç } & 1 \mathrm{~mol} & 1 \mathrm{~mol} & 2 \mathrm{~mol} \\
& 10 \mathrm{~L} & 10 \mathrm{~L} & 10 \mathrm{~L}
\end{array}
$$

Ama başlangıçta girenler kısmında oluyordu, ürünler kısmında olmuyordu. Yanlış yaptım galiba (Ö4)."

Ö4'ün bu şekilde düşünmesinde; başlangıçta tepkenlerin ve ürünlerin karışımının yer aldığı bir denge tepkimesinin olabileceğini anlamlandıramayışı etkili olmuş olabilir.

\section{Formül/bağıntı kullanma}

$\mathrm{Bu}$ sorunun çözümünde öğrencilerin $K_{p}=K_{c} \cdot(R T)^{\Delta n}, \quad \mathrm{Q}_{c}=[\mathrm{HI}]_{\text {baş }}{ }^{2} /\left[\mathrm{H}_{2}\right]_{\text {baş. }}\left[\mathrm{I}_{2}\right]_{\text {baş }}$ ve $\mathrm{K}_{\mathrm{c}}=[\mathrm{HI}]_{\text {denge }}{ }^{2} /\left[\mathrm{H}_{2}\right]_{\text {denge. }}\left[\mathrm{I}_{2}\right]_{\text {denge }}$ formüllerini/bağıntılarını kullandıkları ya da kullanmayı denedikleri görülmüştür. Ancak bu formüllerin ne anlam ifade ettiğini bilmedikleri ve nasıl çıkarıldıklarıyla ilgili fikirlerinin olmadığı ya da nasıl çıkarıldığının derste gösterildiği ancak öğrencilerin hatırlamadıkları belirlenmiştir. Buna ilişkin örnek öğrenci ifadeleri aşağıda sunulmuştur:

“Ö1: Şöyle bir formül vardı $K_{p}=K_{c} \cdot(R T)^{\Delta n}$. Bu formülden bir şey yapabilir miyim diye düşüneyim. 
A: Bu formülün nasıl çıkarıldığını, ne anlama geldiğini biliyor musun?

Ö1: Öğretmenimiz göstermişti. Ben formülü unutmayayım diye ezberlemiştim. Nereden geldiğini hatırlamıyorum. Ama sanırım bu formülü kullanarak çözemeyeceğim. Değiştiriyorum."

“Ö6: $K_{c}$ değerini ürün bölü girenden hesaplarım. Denge sabiti verildiğinde bu formülden hesapliyorduk.

A: Bu formüle nasıl ulaşıldığını ya da ne anlam ifade ettiğini biliyor musun?

Ö6: Aslına bakarsanız bilmiyorum, ilgilenmiyorum da. Çünkü önemli olan soruyu çözebilmek ve sınavda yapabilmek. Bu benim için yeterli."

Yukarıda verilen ilk formülü kullanmayı deneyen bir öğrenci (Ö4) ise bu formülü kullanma nedenini; soruda sıcaklığın verilmesine, formülünde sıcaklık içermesine bağlamış ve şöyle ifade etmiştir:

" $K_{p}=K_{c}(R T)^{\Delta n}$ formülünü yazarım. Çünkü bu formülde sıcaklık kullanılıyor, bir de burada Rydberg sabiti $R$, denge sabiti $K_{c}$ var. Bunları kullanmam için bu formülü yazmam gerekiyor."

Bu düşünce Ö4'ün, tepkime koşullarının belirtilmesi amacıyla verilen niceliklerde dahil soruda verilen tüm niceliklerin mutlaka kullanılması gerektiği fikrine sahip olduğunu düşündürmektedir. Ayrıca bu formülde geçen $\mathrm{R}$ sabiti, ideal gaz sabiti (R) yerine Rydberg sabiti (R) olarak hatalı bir şekilde adlandırılmıştır.

Yukarıda verilen ikinci formülü ise yalnızca iki öğrenci (Ö1, Ö2) kullanmış ve her iki öğrenci de elde ettikleri sonucu önce tepkime oranı, $Q$, olarak değil denge sabiti, $K_{c}$, olarak şöyle yorumlamışlardır:

$"(2 / 10)^{2}=4$ o zaman $K$ değeri 4 oluyor. Ancak soruda denge sabiti 50,3. Öyleyse denge (1/10).(1/10) sabiti artmış oluyor. Nasıl artmış? Demek ki sıcaklık artmış. Sıcaklık kafamı karıştırıyor. Soruyu yeniden çözeyim (Ö1)."

"Formülde yerine yazarsam;

$$
\frac{(2 / 10)^{2}}{(1 / 10) \cdot(1 / 10)}=4 \quad \text { katsayıdan dolayı karesini aldım. }
$$

Denge sabiti $K_{c}^{\prime}$ nin değeri 4 çıkmış olur. Soruda denge sabiti 50,3 verilmiş. O zaman benim bulduğum değer Q değeri ve 4 (Ö2)."

Ö1 ve Ö2'nin ifadeleri incelendiğinde; soruda da $K_{c}$ değeri verildiği için iki öğrencinin de bu değerin ne olduğu konusunda düşündükleri ve Ö1'in hatalı bir değerlendirmeyle formülü kullanmayı bırakıp yukarıda verilen üçüncü formülü kullandığı görülmüştür. Ö2 ise bulduğu değerin tepkime oranı, $Q$, değeri olduğunu fark etmiş, bu değeri $K_{c}$ ile karşılaştırmış ve yukarıda verilen üçüncü formülü kullanarak soruda istenen nicelikleri hesaplamıştır.

\section{Algoritma kullanma}

Bu sorunun çözümü; $Q$ değerinin hesaplanması- $Q$ ve $K_{c}$ değerlerinin karşılaştıılarak sistemin dengede olup olmadığı, dengede değilse net tepkimenin hangi yönde ilerleyeceğine karar verilmesi-BDD (başlangıç-değişim-denge) tablosunun oluşturulması-denge derişimlerinin $\mathrm{K}_{c}$ formülünde yerine koyularak hesaplanması şeklinde ifade edilebilecek bir algoritmayı içermektedir. Bu algoritmayı kullanarak doğru sonuca ulaşan bir öğrenci (Ö2) olmuştur. Yine bir öğrenci de (Ö1) doğru sonuca ulaşmış ancak algoritmanın ilk basamağını kullandığı halde en önemli basamağı olan ikinci basamağını kullanmayarak soruyu aşağıdaki gibi çözmüştür: 
(1/10).(1/10) denge sabiti artmış oluyor. Nasıl artmış? Demek ki sıcaklık artmış. Sıcaklık kafamı karıştırıyor. Soruyu yeniden çözeyim.

$$
\begin{array}{lrll}
H_{2(g)}+I_{2(g)} & \rightleftarrows 2 I_{(g)} \\
1 \mathrm{~mol} & 1 \mathrm{~mol} & 2 \mathrm{~mol} \\
-x & -x & +2 x \quad \text { x kadar harcanacak, 2x kadar oluşacak. } \\
1-x & 1-x & 2+2 x
\end{array}
$$

Katsayılarına bakarak karar verdim. Girenler harcanır, ürünler oluşur. Derişimi bulmak için hacme böleceğim ama zaten sadeleşeceği için yazmıyorum.

$$
\begin{array}{cccc}
(2+2 x)^{2}=50,3 & \frac{\sqrt{(2+2 x)^{2}}}{{\sqrt{(1-x)^{2}}}^{2}}=\sqrt{50,3} & 2+2 x=7 & 2+2 x=7-7 x \\
(1-x) \cdot(1-x) & 1-x & x=5 / 9
\end{array}
$$

Dengeye ulaştığında kapta 1-x=1-5/9=4/9 mol H$, 4 / 9 \mathrm{~mol} \mathrm{I}_{2}, 2+2 x=2+2.5 / 9=19 / 9 \mathrm{~mol} \mathrm{HI}$ olur (Ö1)."

Ö1'in yukarıda verilen düşünceleri incelendiğinde; hesapladığı $Q$ değerini $K_{c}$ olarak ifade ettiği, soruda verilen denge sabiti, $K_{c}$ ile kıyasladığı ve sıcaklığın değiştiğine karar verdiği görülmektedir. Sıcaklığın denge sabitini değiştirdiği doğrudur ve Ö1 bunu bilmektedir. Ancak hesapladığı değerin $K_{c}$ değil $Q$ olduğunun farkında değildir. Bu nedenle zihin karmaşasını yaşadığı, ardından hesapladığı $Q$ değerini de kullanmaktan vazgeçerek BDD tablosunu oluşturduğu, BDD tablosundaki değişimi ise bir denge tepkimesinde mutlaka tepkenlerin harcanacağı fikriyle oluşturduğu söylenebilir.

Aynı soruyu iki öğrenci $(O ̈ 3$, Ö4) yine doğru sonuca ulaşarak çözmüş ancak bu öğrenciler de yukarıda verilen algoritmanın ilk iki basamağını kullanmadan BDD tablosunu oluşturmuş ve bu tablodaki değişimin nasıl olacağına Ö1 gibi düşünerek karar vermiştir. Bir öğrenci (Ö6) ise yukarıda verilen algoritmanın ilk aşamasını yapmış ancak o da Ö1 gibi hesapladığı değerin $\mathrm{K}_{c}$ değeri değil $Q$ değeri olduğunun farkına varamamış ve bulduğu değerle soruda verilen $K_{c}$ değeri arasında ilişki kuramadığı için kafasının karıştığını ifade ederek soruyu çözemeyeceğini ifade etmiştir.

3. SORU: $\mathrm{C}_{(\mathrm{k})}+\mathrm{CO}_{2(\mathrm{~g})} \underset{\mathrm{C}^{\circ}}{\rightleftarrows} \mathrm{CO}_{(\mathrm{g})}$
tepkimesinin $1000{ }^{\circ} \mathrm{C}$ da $\mathrm{K}_{\mathrm{p}}$ değeri $160,0^{\prime}$ tır. $\mathrm{CO}_{2(\mathrm{~g})}$ 'nın dengedeki kısmi basıncı 0,1 atm olarak
ölçüldüğüne göre;
Dengedeki $\mathrm{CO}_{(\mathrm{g})}$ 'in kısmi basıncı kaç atm'dir? Başlangıçta kaç atm $\mathrm{CO}_{2(\mathrm{~g})}, \mathrm{C}_{(\mathrm{k})}$ üzerine eklenmiştir?
Tepkimenin aynı sıcaklıktaki $\mathrm{K}_{\mathrm{c}}$ değerini hesaplayınız.

\section{Kavramları ve kavramlar arası ilişkileri tanımlama}

Üçüncü soruda kısmi basınç, basınç cinsinden denge sabiti $\left(K_{p}\right)$, ve derişim cinsinden denge sabiti $\left(K_{c}\right)$ kavramları yer almaktadır. Bu sorunun çözümünü yaparken yalnızca bir öğrenci (Ö3), kısmi basınç kavramıyla ilgili aşağıdaki açıklamayı yapmıştır:

"Kısmi basınç, gazların basıncı demektir. Öyle değil mi acaba? Ben öyle biliyorum (Ö3)."

Ö3'e ait yukarıda verilen ifadeden kısmi basınç kavramının tam olarak açıklanamadığı fark edilmektedir. Ayrıca kısa ve emin olunmadan yapılan bu açıklamadan, kısmi basınç ile toplam basınç arasındaki fark da anlaşılamamaktadır.

Bu soruyla ilgili iki öğrenci $(0 ̈ 5,0 ̈ 6)$ ise $K_{p}^{\prime}$ 'nin ve kısmi basıncın ne anlama geldiğini bilmediğini açıkça ifade etmiştir. Diğer öğrenciler ise bu kavramlarla ilgili herhangi bir açıklamada bulunmamışlardır. 


\section{Problemde yer alan değişkenleri/verileri yorumlama}

Bu soruda yer alan değişkenlerin/verilerin öğrenciler tarafından nicel olarak anlaşıldığı ancak nitel olarak ne ifade ettiğinin anlaşılmadığı görülmüştür. Ayrıca bir öğrenci (Ö2) tepkimenin gerçekleştiği $1000{ }^{\circ} \mathrm{C}$ çok yüksek bulmuş, tepkimenin oda sıcaklığında gerçekleşmesi gerektiğini düşünmüştür. Bunun nedeni olarak da çoğunlukla sorularda daha düşük sıcaklıklarla karşılaştığını belirtmiştir. Ö2'nin konuya ilişkin ifadeleri şöyledir:

“1000 ${ }^{\circ} \mathrm{C}^{\prime} u$ sorunun çözümünde kullanmam gerekiyor diye düşünüyorum. Normalde oda sıcaklığında olması gerekiyor, genelde böyle düşük sıcaklıkla verilen sorularla karşılaşıyorum. Bu çok yüksek sıcaklık, mutlaka çözümde kullanmam gerekiyor (Ö2)."

Ö2'nin yukarıda verilen ifadelerinden sıcaklığı kullanma gerekçesini yalnızca nicelik olarak fazla oluşuna bağlaması, Ö2'nin sorunun çözümünde kullandığı $K_{p}=K_{c} \cdot(R T)^{\Delta n}$ formülündeki $T^{\prime}$ nin nereden geldiğini ve anlamı üzerinde düşünmediğini dolayısıyla gazların davranışlarından yola çıkarılarak oluşturulan ideal gaz denkleminin bu bağıntıyla olan ilişkisini bilmediğini düşündürmektedir. Sıcaklık değeriyle ilgili iki öğrenci de (Ö4, Ö6) sıcaklığı Celcius'tan Kelvin'e çevirmek gerektiğini ifade etmiştir. Nedeni sorulduğunda ise iki öğrenci de sınava yönelik öğrenme gerçekleştirdiklerinden nedenler üzerinde durmadıklarını söylemiştir. Bu konuya ilişkin örnek öğrenci ifadeleri aşağıda sunulmuştur:

“Ö4: Soruyu çözerken sıcaklığı Kelvin'e çevireceğim.

\section{A: Neden?}

Ö4: Soruları çözerken öyle yapıyoruz. Sebebini öğrenmiyoruz. Genelde sınava yönelik çalışıp, sebebini düşünmeden sadece ezberliyoruz. Önemli olan sınavlarda yapabilmek, o yüzden düşünmüyorum."

Yukarıda verilen ifadeler; gazların davranışları incelenirken sıcaklığın neden K cinsinden alındığı konusunda, özellikle gazların hacmi ile sıcaklık arasındaki ilişkinin incelenmesi sırasında gaz hacminin $\mathrm{K}$ cinsinden sıcaklıkla doğru orantılı olduğuna ilişkin deneysel veriler ve grafikler üzerinde düşünülmediği izlenimi vermektedir.

Bu soruda iki öğrenci (Ö3, Ö6) ise kısmi basıncı mol sayısı olarak düşünebileceklerini söyleyerek soruda verilen $0,1 \mathrm{~atm}$ değerinin $0,1 \mathrm{~mol}$ olarak da kullanılabileceğini ifade etmiştir. Bu ifadeye bir örnek aşağıda sunulmuştur:

“ $\mathrm{CO}_{2}$ 'in kısmi basıncı 0,1 atm olarak ölçülüyor. Buradaki 0,1'i mol sayısı olarak düşünsem.

Çünkü sorularda böyle yapıyorduk (Ö3)."

Ö3 ve Ö6 yukarıdaki düşüncelerinin nedenini sorularda böyle çözdüklerini ifade ederek açıklamaları, düşüncenin kabul edilebilir olduğunu ancak dayanağının sağlam olmadığını göstermektedir.

\section{Formül/bağıntı kullanma}

$\mathrm{Bu}$ sorunun çözümünde öğrencilerin $K_{p}=K_{c} \cdot(R T)^{\Delta n}, \quad \mathrm{~K}_{\mathrm{p}}=\mathrm{P}^{2} \mathrm{co} / \mathrm{P}_{\mathrm{cO} 2}$ ve $\mathrm{K}_{\mathrm{c}}=\left[\mathrm{CO}^{2} /\left[\mathrm{CO}_{2}\right]\right.$ formüllerini/bağıntılarını kullandıkları görülmüştür. Ancak verilen ilk iki formülün ne anlam ifade ettiğini bilmedikleri ve nasıl çıkarıldıklarıyla ilgili fikirlerinin olmadığı ya da nasıl çıkarıldığının derste gösterildiği ama öğrencilerin hatırlamadıkları belirlenmiştir. Üç öğrenci (Ö2, Ö3, Ö4) $K_{p}^{\prime}$ nin yukarıda verilen ikinci formülünde saf katıların ve saf sıvıların yer alamayacağını, gazların ve çözelti halinde olan türlerin yer alabileceğini ifade etmişlerdir. Neden saf katıların ve sıvıların bu formüllerde yer almadığı sorulunca öğrencilerden ikisi (Ö2, Ö4) derste bu şekilde öğrendiklerini söyleyerek geçerli bir neden ileri sürememiştir. Öte yandan $K_{p}$ 'ye ilişkin bağıntıda da çözelti halindeki türlerin yer alabileceğini ifade etmeleri $K_{c}$ ile $\mathrm{K}_{\mathrm{p}}$ arasındaki farkı tam olarak bilemeyişleri ya da bildikleri halde soruyu çözerken ifade 
edemeyerek genelleme yapma eğilimi göstermeleri olabilir. Bu öğrencilerden biri (Ö3) ise hatalı bir şekilde açıklama yaparak; tepkime süresince saf katıların ve saf sıvıların değişime uğramadığını ve bu maddelerin tepkimeye etkilerinin olmadığı için yazılmadığını ileri sürmüştür. Burada tepkimelerde saf katıların ve saf sıvılarında harcanabileceği ya da oluşabileceğinin düşünülmediği görülmektedir. Öğrencinin bu açıklaması kimyasal denge konusundan önce işlenen kimyasal tepkimelerde hız konusunda ele alınan katalizörün etkilerinin bu açıklamaya uyarlandığı gibi bir izlenim vermektedir. Öğrencinin açıklamasının sonunda saf sıvıların ve saf katıların derişimlerinde değişme olmadığını belirtmeye çalışması göze çarpmakta ancak bunu ifade etmekte zorlandığı görülmektedir. Ö3'ün açıklamalarına ait bir bölüm aşağıda sunulmuştur:

“Ö3: Kp'de saf katılar yazılmaz. Sadece gazlar yazılır?

\section{A: Neden katılar yazılmaz?}

Ö3: Onların tepkimeye girişinde ve çıkışında hiçbir etkisi olmadığı için ve tepkimede değişime uğramadıkları için yazılmıyor. Sıvılar ve katılar denklem boyunca değerleri değişmediği için yazılmıyor, öyle biliyorum."

Aynı öğrenci (Ö3) $K_{p}=K_{c}$. $(R T)^{\Delta n}$ formülünde geçen R sabitini, ideal gaz sabiti (R) yerine Rydberg sabiti (R) olarak hatalı bir şekilde adlandırmıştır. Ayrıca bu üç öğrenci (Ö2, Ö3, Ö4) $\Delta$ n değerini ürünlerden girenlerin mol sayısının çıkarılması şeklinde değerlendirerek ürünlerin mol sayısını 2 , tepkenlerin mol sayısını da 2 almış ve $\Delta$ n değerini 0 bulmuştur. Halbuki aynı öğrenciler, saf katıların denge bağıntısında yer alamayacağını ifade etmelerine rağmen $\Delta \mathrm{n}$ değerini hesaplarken $C_{(k)}$ 'nın mol sayısını hesaplamaya dahil etmişlerdir. Burada öğrencilerin aceleci davrandıklarından ya da ifade ettiklerini pratik etmedeki deneyim azlığından dolayı böylesi bir hata yaptıkları söylenebilir.

\section{Algoritma kullanma}

$\mathrm{Bu}$ soru aslında üç soruyu içerdiğinden çözümü için de üç algoritma kullanmak gereklidir. CO'in kısmi basıncını bulmak için $\mathrm{K}_{\mathrm{p}}=\mathrm{P}_{\mathrm{CO}}{ }^{2} / \mathrm{P}_{\mathrm{CO} 2}$ bağıntısında verileri yerine koyarak CO'in kısmi basıncının bulunmasını içeren tek aşamalı bir algoritma kullanılır. Bu algoritmayı kullanarak doğru sonuca ulaşan iki öğrenci (Ö1, Ö3) olmuştur. Bir öğrenci (Ö4) yalnızca tepkime denkleminde yer alan türlerin stokiyometrik katsayılarını dikkate alarak CO'in kısmi basıncının $\mathrm{CO}_{2}{ }^{\prime}$ in kısmi basıncının iki katı dolayısıyla 0,2 atm olması gerektiğini söyleyerek yanlış çözmüştür. Diğer öğrenciler ise çözüm sunamamışlardır.

Bu soruda kullanılacak ikinci algoritma, başlangıçtaki $\mathrm{CO}_{2}$ 'in kısmi basıncını bulmaya yöneliktir. Bunun için BDD tablosunun oluşturulması (bu aşama için gereken $\mathrm{CO}^{\prime}$ in dengedeki kısmi basıncı, sorunun ilk kısmında hesaplanmıştı)-denge sistemindeki türlerin kısmi basınçlarının $K_{p}$ formülünde yerine konularak hesaplama yapılması gerekmektedir. Ancak öğrencilerin hiçbiri bu algoritmayı uygulamamış, farklı bir çözüm yolu önerememiş ve soruyu çözememiştir.

$\mathrm{Bu}$ soruda kullanılacak üçüncü algoritma, denge tepkimesinin aynı sıcaklıktaki $\mathrm{K}_{\mathrm{c}}$ değerinin hesaplanmasına yöneliktir. Bunun için $K_{p}$ ve $K_{c}$ arasındaki ilişkiyi veren bağıntının yazılması, $K_{p}=K_{c} \cdot(R T)^{\Delta n}$-verilerin yerine yazılarak $K_{c}$ değerinin hesaplanması gerekmektedir. Yalnızca bir öğrenci (Ö1) bu algoritmayı kullanarak soruyu çözmüş ve doğru sonuca ulaşmıştır. Üç öğrenci de (Ö2, Ö3, Ö4) bu algoritmayı kullanmış ancak doğru sonuca ulaşamamıştır. Çünkü yukarıda da ifade edildiği gibi $K_{p}=K_{c} \cdot(R T)^{\Delta n}$ bağıntısındaki $\Delta$ n değerini yanlış hesaplayarak 0 bulmuşlar ve neticede $K_{p}=K_{c}=160$ sonucuna ulaşmışlardır. Bir öğrenci (Ö6) ise algoritmanın ilk aşamasını yapmış ancak ikinci aşaması olan verileri yerleştirme aşamasında zihin karmaşasına düşmüş ve bu durumu aşağıdaki gibi ifade etmiştir: 
"Kp değerini 160 olarak yazacaktım ama soruda kısmi basıncı da vermiş. Hangi değeri yerine koyacağım 0,1 mi, $160 \mathrm{mı}$ ? (Ö6)"

Ö6'nın soruyu çözerkenki ifadeleri $K_{\mathrm{p}}$ ve kısmi basınç kavramlarını tam olarak anlamadığını, bu iki kavram arasındaki farkı ve ilişkiyi de değerlendiremediğini ve bu durumun soruyla karşı karşıya kalmasıyla açığa çıktığını düşündürmektedir. Bir öğrenci (Ö5) ise sorunun çözümünde kullanması gereken formülü hatırlamadığı için soruyu çözemeyeceğini şu şekilde ifade etmiştir:

"Derste böyle sorular çözmüştük ama hatırlayamıyorum. Bir gün öncesinde çalışsam yapardım. Derste de çözebiliyorum. Tahtada formül oluyor. Soruda verilenleri o formülde yerine koyarak yapabiliyorum (Ö5)."

4. SORU: Sabit sıcaklıkta 1 L'lik kapalı bir kapta $0,2 \mathrm{~mol} \mathrm{H}_{2(\mathrm{~g})}, 0,2 \mathrm{~mol} \mathrm{I}_{2(\mathrm{~g})}$ ve 0,4 $\mathrm{mol} \mathrm{HI}_{(\mathrm{g})}$ $\mathrm{H}_{2(\mathrm{~g})}+\mathrm{I}_{2(\mathrm{~g})} \rightleftarrows 2 \mathrm{HI}_{(\mathrm{g})}$

denklemine göre dengededir. Kaba, sabit sıcaklıkta $0,8 \mathrm{~mol} \mathrm{HI}_{(\mathrm{g})}$ ilave ediliyor. Aynı sıcaklıkta yeniden denge kurulduğunda, kapta kaç mol $\mathrm{H}_{2(\mathrm{~g})}$ bulunur?

\section{Kavramları ve kavramlar arası ilişkileri tanımlama}

Öğrencilerin çözmesi istenen son soruda denge kavramı yer almaktadır. Bu kavramla bağlantılı olarak; net tepkimenin sağa ya da sola kayması, tepkime oranı $(Q)$, Le Chatelier ilkesi, yeniden denge kurulması gibi kavramlar da bulunmaktadır. Bu nedenle bu sorunun çözümünde öğrencilerin bu kavramlarla ilgili temel bir anlayışa sahip olmaları gerekmektedir. Ancak öğrencilerin soru çözümlerine bakıldığında bazı öğrencilerin (Ö2, Ö3, Ö6) denge kavramıyla ilgili kavram yanılgılarına sahip oldukları görülmüştür. Her üç öğrenci de kimyasal denge kavramını, kavram yanılgılı bir şekilde günlük yaşamdaki terazi dengesine benzetmiştir. Bu duruma ilişkin örnek öğrenci ifadeleri şöyledir:

"Dengeyi şu şekilde düşünebiliriz. Bir terazi düşünelim. Sağ tarafa bir ağırlık getirdik, sol tarafa da eklememiz gerekiyor. Ya da sağdan çıkardığımızda soldan da çıkarmamız gerekiyor ki denge sağlansın (Ö2)."

"A: Tepkime dengededir sana ne ifade ediyor?

Ö6: Yani belirli miktarlarda mol sayısı girdiğinde eşit olacak, şeyleri dengede oluyorlar, miktarları."

Soruda denge durumundaki sisteme ürünlerden $\left(\mathrm{HI}_{(\mathrm{g})}\right)$ bir miktar eklendiği bilgisi yer almaktadır. Soruyu çözmek için denge durumunun bozulacağının ve net tepkimenin hangi yöne ilerleyeceğinin belirlenmesi gerekir. Bu sırada dengenin sağa ya da sola kayması kavramı ortaya çıkmaktadır. Bu kavramın ne anlama geldiği ve dengenin sağa mı yoksa sola mı kayacağının nasıl ön görüleceği öğrencilere sorulduğunda, tatmin edici açıklamalar yapamadıkları ve dengenin yönü konusunda başvurulması gereken tepkime oranı, Q, ve Le Chatelier ilkesi (denge sistemi sabit hacimli kapta bulunduğu ve dışarıdan tek bir etki yapıldığı için Le Chatelier ilkesi kullanılabilir) gibi kavramlara başvurmadıkları görülmüştür. Konuya ilişkin örnek olabilecek öğrenci ifadeleri aşağıda sunulmuştur:

\section{“A: Dengenin kayması ifadesini kullandın. Dengenin kayması ne anlama geliyor? \\ Ö1: Yani bir tarafta madde eklendiğinde öbür tarafta madde oluşuyor. (Tepkime denkleminde tepkenler tarafını göstererek) Bu tarafa kayıyor."}

Öğrencilerin yarısından fazlası (Ö1, Ö2, Ö4, Ö6) doğru bir şekilde dengenin tepkenlere kayacağını düşünmüştür. Ancak bu düşüncelerinin dayanağı, kavram yanılgılıdır. Öğrencilerdeki yukarıda da ifade edilen "terazi dengesi" yanılgısının, denge sistemine dışarıdan herhangi bir etki yapıldığında dengenin yönünün nasıl değişeceğini tahmin etmede hataya düşmelerine neden olduğu görülmüştür. Bazı öğrenciler (Ö1, Ö2, Ö4, Ö6) ürün miktarında artış olduğunda tepken miktarında da artış olmalıdır ki ya da ürün miktarındaki artışı azaltacak bir etki olmalıdır 
ki denge sağlanabilsin görüşünü dile getirmişlerdir. Öğrenci görüşlerini yansıtan ifadelere örnek aşağıda verilmiştir:

"Ö6: 0,8 mol HI eklendiğinde denge girenlere kayacak.

A: Neden?

Ö6: Mol sayısı artışını dengelemek için, dengeyi sağlamak için.

A: Girenlere kaymasını neye göre belirledin?

Ö6: Mantıken ürünler arttığında onun azalması veya dengelenmesi gerekiyor. Ama neye göre bilmiyorum. Ancak (ürünleri göstererek) biri artarken, (tepkenleri göstererek) şuradan bir kuvvet artırması veya (ürünleri göstererek) azaltması gerekiyor. Dengeyi tekrar sağlayabilmek için."

Yukarıda verilen örnek ifadeler; dengedeki bir sisteme dışarıdan herhangi bir etki yapıldığında dengenin yönünün nasıl değişeceğinin, dışarıdan yapılan herhangi bir etki sonucu ileri ve geri yöndeki tepkime hızlarındaki değişmeye dayalı olmadığını, terazi dengesinde olduğu gibi terazinin bir kefesine yapılan ilaveyi karşılamak için diğer kefeye de madde ilave edilmesi gerektiği gibi bir düşünceye dayandığını göstermektedir.

Öğrencilerden biri (Ö2) ise dengenin yönünün tepkenlere kayacağını doğru bir şekilde ifade etmesine rağmen dışarıdan $0,8 \mathrm{~mol} \mathrm{HI}$ ilave edildiğinde tepkenlerdeki yalnızca $\mathrm{H}_{2(\mathrm{~g})}$ 'nın (soruda $\mathrm{H}_{2(g)}$ sorulduğu için) miktarını artırmak gerektiğini böylece dengenin sağlanabileceğini düşündüğünü söylemiştir. Öğrencinin soru çözümü incelendiğinde bu düşüncenin yanılgılı bir şekilde; $\mathrm{HI}_{(\mathrm{g})}$ 'nın harcanarak $\mathrm{H}_{2(\mathrm{~g})}$ oluşturmasına değil dışarıdan eklenmesine dayalı olduğu görülmüştür. Bu öğrenciye ait konuya ilişkin ifadelerden bir kesit aşağıda sunulmuştur:

“Ö2: 0,8 mol Hl eklendiğine göre aynı zamanda ben $\mathrm{H}_{2}{ }^{\prime} y$ i de artırmamı gerektiğini düşünüyorum.

A: Neden?

Ö2: ...Terazide bir taraf ağırlaşırken diğer tarafı da ağırlaştırmamız gerekiyor $k i$ böldüğümüzde yine aynı oran çıssın."

\section{Problemde yer alan değişkenleri/verileri yorumlama}

Bu soruda yer alan değişkenlerin/verilerin bir öğrenci (Ö4) dışında diğer öğrenciler tarafından ne ifade ettiğinin anlaşıldığı görülmüştür. Bahsedilen öğrenci ise tepkimede yer alan türlerin mol sayılarını, dengedeki mol sayıları olarak değil başlangıçtaki mol sayıları olarak düşünmüş ve ona göre soruyu çözmeye çalışmıştır.

\section{Formül/bağıntı kullanma}

$\mathrm{Bu}$ sorunun çözümünde öğrencilerin (Ö5 hariç) $\mathrm{K}_{\mathrm{c}}=\left[\mathrm{HI}_{(\mathrm{g})}\right]^{2} /\left[\mathrm{H}_{2(\mathrm{~g})}\right] \cdot\left[\mathrm{I}_{2(\mathrm{~g})}\right]$ bağıntısını kullandıkları görülmüştür. Öğrenciler bu bağıntıyı ürün $\left(0,8 \mathrm{~mol} \mathrm{HI}_{(\mathrm{g})}\right)$ ilave edilmeden önceki ve edildikten sonraki sistemin denge sabitini hesaplamak için kullanmışlardır. Bu kullanım sırasında sıcaklığın denge sabitini değiştirdiğini ancak soruda sıcaklık değişimi olmadığı için iki durumda da $\mathrm{K}_{\mathrm{c}}$ değerinin aynı olacağını bilerek kullanmışlardır. Ancak yukarıda diğer soruların analizinde verilen $\mathrm{K}_{\mathrm{c}}$ değerinin ne anlam ifade ettiği ve nasıl elde edildiğiyle ilgili belirttiklerinin dışında herhangi bir açıklamada bulunmamışlardır.

\section{Algoritma kullanma}

Bu sorunun çözümü; DEDD (I. Denge-Etki-Değişim-Il. Denge) tablosu oluşturma-I. dengeye yapılan etkinin dengenin yönünü nasıl değiştireceğine tepkime oranı (Q) veya Le Chatelier ilkesini (denge sistemi sabit hacimli kapta bulunduğu ve dışarıdan tek bir etki yapıldığı için Le Chatelier ilkesi kullanılabilir) kullanarak belirleme-değişimleri DEDD tablosunun değişim 
aşamasına yazma-I. denge derişimlerinin $K_{c}$ formülünde yerine yazarak $K_{c}^{\prime} y i$ hesaplama(Sıcaklık değişmediği için denge tepkimesine ait $K_{c}$ değeri de değişmeyeceğinden) II. denge derişimlerini $\mathrm{K}_{\mathrm{c}}$ formülünde yerine koyarak değişimi $(\mathrm{x})$ hesaplama- $\mathrm{H}_{2(\mathrm{~g})}{ }^{\prime} \mathrm{n}$ !n II. dengedeki derişimini $(0,2+x)$ hesaplama şeklinde ifade edilebilecek bir algoritmayı içermektedir. Ancak bu algoritmanın tamamını doğru bir şekilde kullanan herhangi bir öğrenci olmamıştır. Öğrencilerin bu algoritmanın ikinci ve üçüncü aşamalarında yanılgıya düştükleri görülmüştür. Öğrencilerin hiçbiri, dengeye yapılan etkinin dengenin yönünü nasıl değiştireceğini belirlemeyi içeren ikinci aşamada, tepkime oranını ( $Q$ ) ya da Le Chatelier ilkesini kullanmamıştır. Öğrenciler, dengenin hangi yöne kayacağını (tepkenler yönüne) doğru bir şekilde belirlemişler ancak bu belirlemeye gösterdikleri dayanak hatalı olmuştur. Öğrencilerin bu hatalı dayanakları bir noktada toplanmıştır. O nokta da; ürün miktarındaki artıştan dolayı tepken miktarında da artış olması gerekir (terazi dengesi düşüncesine dayanarak) bu nedenle dengenin sola (tepkenler yönüne) kayması gerekir düşüncesidir. Öğrenciler yukarıda kavramları ve kavramlar arasındaki ilişkileri tanımlama kısmında verilen alıntılardaki açıklamaları yaparak soruyu çözmüşlerdir. Dengenin yönünü hatalı bir dayanakla doğru bir şekilde belirleyen öğrencilerin tamamı DEDD tablosunu, değişim aşamasından itibaren hatalı bir şekilde oluşturmuştur. Bu duruma bir örnek aşağıda verilmiştir:

$$
\begin{aligned}
& \text { "Ö1: } H_{2(g)}+I_{2(g)} \rightleftarrows 2 I_{(g)} \\
& 0,2 \mathrm{~mol} \quad 0,2 \mathrm{~mol} \quad 0,4 \mathrm{~mol} \\
& +0,8 \mathrm{~mol} \quad\left[\mathrm{H}_{2(g)]}\right] \cdot\left[I_{2(g)}\right] \quad(0,2) \cdot(0,2) \\
& +x \quad+x
\end{aligned}
$$

$0,2 \mathrm{~mol}+x \quad 0,2+x \mathrm{~mol} \quad 1,2 \mathrm{~mol} \quad$ Hacim 1 L olduğundan mol sayısı ile derişim değerleri aynı olur.

$$
K c=\frac{(1,2)^{2}}{(0,2+x) \cdot(0,2+x)}=4 \quad \frac{K c=\sqrt{(1,2)^{2}}=\sqrt{4}}{\sqrt{(0,2+x)^{2}}} \quad 1,2=2 \cdot(0,2+x) \quad 1,2=0,4+x \quad x=0,8
$$

$H_{2(g)^{\prime}}$ 'ın miktarı $0,2+0,8=0,2+0,8=1,0^{\prime \prime}$

Yukarıda örneği verilen çözümde, DEDD tablosunda $\mathrm{HI}_{(g)}$ 'nın harcandığının göz ardı edildiği görülmektedir. Bu durum diğer öğrenci açıklamalarıyla birlikte değerlendirildiğinde, öğrencilerin ürünlerden tepkenlerin oluştuğunun farkında oldukları ancak ürünlerdeki artıştan dolayı tepkenlerdeki artışa odaklandıkları için ürünlerin bir miktar harcanacağının farkında olmadıkları anlaşılmıştır. Ayrıca bir öğrenci (Ö2) de yukarıda alıntısı verilen algoritmayı kullanarak soruyu çözmüş ancak DEDD tablosunun değişim aşamasında sadece $H_{2(g)}{ }^{\prime}$ nda $x$ kadar artış olacağını göstermiş ve ona göre çözüm yapmıştır. Bu öğrencinin açıklamalarından dengenin kurulabilmesi için $\mathrm{H}_{2(\text { g) }}$ miktarındaki artışın, dışarıdan bir etkiyle yapılması gerektiğini düşündüğü anlaşılmaktadır. Öğrencinin bu hatalı çözümünde dengeyi, terazi dengesine benzetmesinin ve buna göre soruyu yorumlamasının neden olduğu düşünülmektedir.

Bu sorunun çözümünde bir öğrenci (Ö6) ise yukarıda verilen algoritmanın ikincisi aşamasını hiç kullanmamıştır. Dolayısıyla dengeye yapılan etkinin denge durumunu bozacağına ve net tepkimenin yönünün tepkenlere doğru olacağına ilişkin hiçbir çıkarımda bulunmamıştır. Bu nedenle DEDD tablosunun değişim aşamasını bir kimyasal tepkimede daima tepken harcanır düşüncesine dayanarak;

$$
\begin{aligned}
& \begin{array}{c}
\mathrm{H}_{2(g)}+\underset{I_{2(g)}}{\rightleftarrows} 2 \mathrm{HI}_{(g)} \\
0,2 \mathrm{~mol} \\
0,2 \mathrm{~mol}
\end{array} \\
& +0,8 \mathrm{~mol}
\end{aligned}
$$




\section{$-x \quad-x$ \\ 0,2 mol-x $\quad 0,2-x \mathrm{~mol} \quad 1,2 \mathrm{~mol}(0 \ddot{6})^{\prime \prime}$}

şeklinde oluşturmuş ve soruyu bu hataya bağlı olarak yanlış çözmüştür.

Bir başka öğrenci (Ö4) de soruyu Ö6 gibi çözmüş ancak DEDD tablosu yerine sistemin dengede olduğunu ve dengedeki mol sayılarını göz ardı ederek BEDD (başlangıç-etki-değişim-denge) tablosu oluşturarak soruyu yanlış çözmüştür. Son olarak bir öğrenci (Ö5) ise yukarıda verilen algoritmayı herhangi bir biçimde kullanmaksızın yalnızca 'ürün miktarındaki artıştan dolayı (terazi dengesinde olduğu gibi) tepken miktarında da artış olacaktır ve bu artış tepkimenin stokiyometrik katsayılarına bağı olarak gerçekleşecektir' düşüncesine dayanarak soruyu aşağıda belirtildiği şekilde çözmeye çalışmışır:

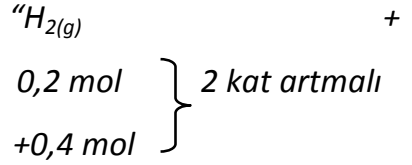

$0,6 \mathrm{~mol}$

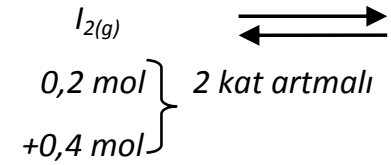

$0,6 \mathrm{~mol}$

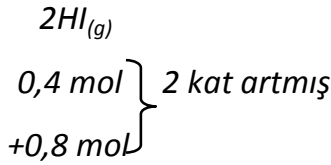

$1,2 \mathrm{~mol}$

$H_{2(g)}$ nın mol sayısı 0,6 mol (Ö5)."

\section{SONUÇ, TARTIŞMA VE ÖNERILER}

Araştırmanın bu bölümünde verilerin analizinde kullanılan temalar dikkate alınmış ve tartışmaya tema başlıkları altında yer verilmiştir.

\section{Kavramları ve kavramlar arası ilişkileri tanımlama}

Çalışma kapsamında kimyasal denge konusuyla ilgili sorulan algoritmik sorular; denge, denge sabiti, ileri yönde tepkime hız sabiti, geri yönde tepkime hız sabiti, derişim, kısmi basınç, basınç cinsinden denge sabiti $\left(\mathrm{K}_{\mathrm{p}}\right)$, derişim cinsinden denge sabiti $\left(\mathrm{K}_{\mathrm{c}}\right)$, dengenin sağa ya da sola kayması, tepkime oranı (Q), Le Chatelier ilkesi ve yeniden denge kurulması şeklindeki kavramları içermekte ya da bu kavramları ve kavramlar arası ilişkiyi düşünmeyi gerektirmektedir. Öğrencilerden bu kavramları içeren algoritmik soruları çözerken sesli düşünmeleri ve bu yolla kavramlara yükledikleri anlamı açığa vurmalarının beklendiği ifade edilmiştir. Ancak şunu belirtmek gerekir ki öğrencilerin sesli düşünmelerini sağlamak kolay olmamıştır. Öğrencilere sesli düşünme yönergesi verilip kendilerinden beklenenler detaylıca açıklanmasına rağmen sesli düşünme konusunda çekindikleri, düşüncelerini kısık sesle ifade ettikleri, sıklıkla düşüncelerini ifade ederek soruları çözmek yerine yalnızca yazılı olarak çözmeye yöneldikleri gözlemlenmiştir. Bu nedenlerden dolayı öğrenciler sık sık sesli düşünmeleri konusunda nazikçe uyarılmış, onları sesli düşünmeye teşvik etmek için bazı sorular sorulmuştur.

Öğrencilerin sorularla ilgili kavramlara yönelik yaptıkları açıklamalar incelendiğinde ise açıklamaların oldukça sınırlı ve yetersiz olduğu tespit edilmiştir. Bununla ilgili olarak kimyasal denge kavramıyla ilgili açıklamalardan bir tanesinin ilgisiz (Ö5), üç tanesinin ise hatalı (Ö1, Ö2 ve Ö6) olduğu tespit edilmiştir. Bu hatalardan birinin kimyasal denge kavramını açıklarken tepkime hızı ile tepkime hız sabiti kavramlarıyla ilgili olarak düşülen karmaşadan dolayı, diğer ikisinin ise denge kavramını günlük yaşamdaki terazi dengesine benzeterek kütle eşitliği olması gerektiği düşüncesinden kaynaklandığı bulunmuştur. Bir öğrencinin (Ö3) ise sorulan soruların birinde denge kavramıyla ilgili eksik açıklama yaptığı ancak bir başka soruda yaptığı açıklamayla -denge kavramını günlük yaşamdaki terazi dengesine benzeterek kütle eşitliği üzerinden açıklama- kavramla ilgili kavram yanılgısına sahip olduğu anlaşıımıştır. Derişim (Ö1) ve tepkime oranı (Ö2) kavramlarıyla ilgili birer öğrencinin bilimsel olarak doğru kabul edilebilecek 
açıklamalar üretebildikleri, $K_{c}$ ile $Q$ arasındaki ilişkiyi bir öğrencinin (Ö2) doğru olarak açıklayabildiği, tepkime hız sabiti ve kısmi basınç kavramlarını bir öğrencinin açıklamaya çalıştığı ancak bu konuda zorlandığı ve tatmin edici açıklama üretemediği, denge sabiti kavramını bir öğrencinin eksik (Ö3), bir öğrencinin (Ö5) ise açıkça üzerinde düşünmediğini ifade ettiği, yine $K_{p}$ ve kısmi basıncın ne anlama geldiğini bilmediğini iki öğrencinin (Ö5, Ö6) açıkça ifade ettiği görülmüştür. Bunların dışında öğrenciler, herhangi bir açıklama yapmamış ve düşüncelerini ifade etmemişlerdir. Tüm bu bulgular dikkate alındığında; öğrencilerin kimyasal denge konusu kapsamında yer alan ve yukarıda ifade edilen kavramlara ilişkin temel düzeyde de olsa bir anlayış geliştirdiklerini söylemenin güç olduğu ifade edilebilir. Bu durum, Türkiye'de yükseköğretime geçiş için yapılan LYS (Lisans Yerleştirme Sınavı) ile birlikte değerlendirildiğinde daha iyi anlaşılabilir. Örneğin Öğrenci Seçme ve Yerleştirme Merkezi'nin 2015 verilerine göre sınavı geçerli olan 400.610 adayın 30 soruluk kimya testinde ortalama 8,75 soruyu doğru yanıtladıkları, standart sapmanın ise 6,88 olduğu görülmektedir (ÖSYM, 2015). Burada ortalamanın düşüklüğü ve standart sapmanın büyüklüğü dikkat çekmektedir. Adı geçen testte, kimyasal denge konusuyla ilgili iki adet sorunun yer aldığı ve bu soruların da yukarıda ifade edilen kavramların pek çoğunu içerdiği tespit edilmiştir. Aynı verilerde okul türlerine göre puan dağıımına da yer verilmiştir. Bu açıdan bakıldığında bu çalışmanın da evrenini oluşturan Anadolu Liselerinin (bu liselerden sınavı geçerli 139.311 aday) 2015-LYS MF (Matematik-Fen) puanları ortalaması 500 puan üzerinden 253,228'dir. Bu puan her ne kadar Matematik ve Fen (Fizik, Kimya, Biyoloji) sorularının toplamından elde edilen puan üzerinden yapılan değerlendirmeyi içerse de yukarıda verilen veriler birlikte düşünüldüğünde; kimya konuları kapsamındaki kavramların öğrenciler tarafından yeterince anlaşılamadığı söylenebilir. Bu durum pek çok çalışmada da ifade edilmiştir (Childs \& Sheehan, 2009; Çelik, Canpolat, Pınarbaşı, Sözbilir \& Bayrakçeken, 2007; Woldeamanuel, Atagana \& Engida, 2014).

\section{Problemde yer alan değişkenleri/verileri yorumlama}

Öğrencilerin problemde yer alan değişkenleri/verileri yorumlamada en çok birinci soruda zorlandıkları görülmüştür. Bunun nedeni; bazı öğrencilerin denge sabitinin, ileri ve geri yöndeki tepkime hız sabitlerinin kullanılması suretiyle hesaplandığı soru tipleriyle karşılamamaları olabilir. Ancak böyle olsa dahi, kimyasal denge, tepkime hızı ve hız bağıntısı kavramlarını ve bu kavramlar arasındaki ilişkiyi bilen bir öğrencinin; denge sabitini, ileri ve geri yöndeki tepkime hız sabitlerini kullanarak hesaplaması beklenebilir. Zaten bu sınıf seviyesine ait kimya öğretim programı, böylesi bir hesaplamanın teorik olarak izahının verilmesini içermektedir (Talim Terbiye Kurulu Başkanlı̆̆ı [TTKB], 2011). Öğrencilerin bir kısmının bu hesabı yapamaması, daha önce öğrendiklerini karşılaştıkları bir problemin çözümünde kullanılabilecek forma dönüştürmede (Galbraith, 1998) güçlük yaşadıklarını düşündürmektedir. Öğrenciler, daha önce benzer bir soru çözmüş olsalardı bu soruyu da kolaylıkla çözebileceklerini ifade etmişlerdir. Öte yandan soruyu çözen diğer öğrenciler, soruda yer alan denge derişimlerine ilişkin verileri, kimyasal tepkimelerde hız konusuyla ilgili bir soruyu çözmede kullanılan algoritmanın uygulandığı veriler olarak -hatalı bir şekilde- değerlendirmişlerdir. Bu iki durum; öğrencilerin problem çözerken bilgiyi taklit etmeye ve benzerini oluşturmaya, bilgiyi kullanma ve dönüştürmeden daha fazla eğilim gösterdiklerini düşündürmektedir. Oysa 21. yüzyıl toplumlarının bireylerinin sahip olması beklenen önemli özelliklerinden biri de bilgi okuryazarlığıdır. Bilgi okuryazarlığı; bilgiye ulaşma, bilgiyi değerlendirme, kullanma ve yönetme becerilerini içermektedir (Köğce, Özpınar, Mandacı Şahin \& Aydoğan Yenmez, 2014; Partnership for $21^{\text {st }}$ Century Learning, 2015; Trilling \& Fadel, 2009). Ancak yukarıda ifade edilenler, bilgi okuryazarlı̆̆ bağlamında değerlendirildiğinde; öğrencilerin düşünme biçimleri ile bilgi okuryazarı bireylerin düşünme biçimleri arasında uyum olmadığı söylenebilir. Bu yorumu, öğrencilerin üçüncü sorudaki değişkenleri/verileri yorumlarken açığa vurdukları 
düşünceleri destekler niteliktedir. Bu sorunun çözümü sırasında bazı öğrenciler, soruda yer alan bazı değişkenleri/verileri ezbere dayalı olarak yorumladıklarını, üniversiteye giriş sınavına yönelik olarak öğrenme gerçekleştirdikleri için sorgulama ve üzerinde düşünme gereği duymadıklarını açıkça ifade etmişlerdir.

\section{Formül/Bağıntı Kullanma}

Öğrencilerin algoritmik soruları çözerken, kullanılması gereken formülleri/bağıntıları çoğunlukla kullandıkları ya da kullanmayı denedikleri gözlenmiştir. Öğrencilerden bazıları bu formüllerin/bağıntıların ne anlama geldiğiyle ve nasıl çıkarıldığıyla ilgili fikirlerinin olmadığını, bazıları ise derste gösterildiğini ancak hatırlamadıklarını ifade etmişlerdir. Bir öğrencinin (Ö4, 2. soru) tepkime koşullarını tanımlamak için verilen niceliği (sıcaklık) mutlaka kullanmak gerektiğini düşünerek, içinde bu niceliği barındıran formülü/bağıntıyı kullanma eğilimi gösterdiği tespit edilmiştir. Yine bir öğrenci (Ö1, 2. soru) ise kullandığı bağıntıdan elde ettiği sayısal sonucun, hangi niceliği ifade ettiğini hatalı bir şekilde yorumlamıştır. Ayrıca bazı öğrencilerin (Ö2, Ö3 ve Ö4, 3. soru) kullandıkları bağıntıdaki niceliğin nasıl hesaplanacağını bildikleri ancak pratikte hata yaptıkları belirlenmiştir. Tüm bu veriler birlikte düşünüldüğünde kimyasal problemlerin çözümünde kullanılan formüllerin/bağıntıların öğrenciler tarafından ezberlendiği, ne anlama geldiği ve nasıl elde edildiğiyle ilgili fikirlerinin olmadığı ve bunu da önemsemedikleri söylenebilir. Aslında bu durum; formüllerin/bağıntıların kalıp bilgi dolayısıyla da bilimin hazır bilgi yığını (Çobanoğlu, 2013, s. 69) olarak görülmesine ve kimyanın bir insan uğraşısı olarak takdir edilmemesine katkı sağlayabilir (Bayrakçeken, Canpolat ve Çelik, 2011). Öğrencilerdeki böylesi bir düşünce, onların bilimin doğasıyla ilgili doğru anlayışlar geliştirmelerine olumsuz yönde etki edebilir. Bu nedenle kimya konuları kapsamında öğretilen formüllerin/bağıntıların kimya karşılıklarının ve kimyasal temellerinin öğrencilere kavratılmasının önemli olduğu ifade edilebilir.

\section{Algoritma Oluşturma}

Öğrencilerin problemleri çözerken kullandıkları algoritmalar incelendiğinde; algoritmanın bazı basamaklarının doğru, bazı basamaklarının ise eksik veya hatalı bir şekilde yapılandırıldı̆ı tespit edilmiştir. Bu duruma; sahip oldukları bazı kavram yanılgılarının, kimyayla ilgili yetersiz anlayışlarııın (Weerawardhana, 2006), bilgilerinden emin olamayışlarının, bilgilerini transfer edemeyişlerinin ve kimya bağlamında yorum yapamayışlarının (Parchmann, Broman, Busker \& Rudnik, 2015, s. 267) neden olduğu söylenebilir. Burada dikkat çeken nokta; eksik ya da hatalı algoritma kullanmasına rağmen bazı öğrencilerin (Ö1, Ö3 ve Ö4, 2. soru) doğru sayısal sonuca ulaşmasıdır. Oysa bu öğrenciler, kimyasal olarak hatalı düşünme biçimiyle doğru sonucu bulmuşlardır. Şayet bu sorular, çoktan seçmeli soru tipinde sorulsaydı; öğrenciler soruyu bu yolla çözmelerine rağmen doğru seçeneği işaretledikleri için doğru yaptıkları kabul edilecekti. Bu bağlamda da konuyla ilgili olarak akademik anlamda başarılı varsayılacaklardı. Oysa sorunun çözümüne götüren algoritmanın her bir basamağına ilişkin öğrencilerin düşünceleri incelendiğinde; hatalı ve kimya temeline dayanmayan bazı düşüncelere rastlanmıştır. Bu durum, konunun öğrenciler tarafından derinlemesine bir anlayış geliştirilmeden başka bir ifadeyle yüzeysel öğrenildiğini ve ulusal sınavlardaki seçenekli sorulardan doğru seçeneği işaretlemeye yönelik olarak öğrenme gerçekleştirdiklerini düşündürmektedir (Özden, 2007).

Sonuç olarak bu çalışma; öğrencilerin kimyasal dengeyle ilgili algoritmik sorularda yer alan önemli kavramlarla (kimyasal denge, denge sabiti, Le Chatelier ilkesi gibi) ilgili açıklamalarının yetersiz olduğunu, sorularda yer alan değişkenleri/verileri yorumlamada daha önce benzer soruları çözüp çözmemenin etkili olduğunu, soru çözümünde kullanılması gereken formülleri/bağıntıları çoğunlukla kullanabildikleri ancak bu formüllerin/bağıntıların kimyadaki karşılıklarıyla ilgili yeterli anlayışlarının olmadığını ve soruların çözümünde çoğunlukla eksik ya 
da hatalı algoritma kullandıkları ancak bu kullanıma rağmen bazı soruların doğru sayısal cevaplarına ulaşabildiklerini ortaya koymaktadır. Bu sonuçlar yukarıdaki tartışmalar birlikte değerlendirildiğinde; kimyayla ilgili içeriğin öğrenilmesinde sorunlar olduğu söylenebilir. Kimyayla ilgili bilgi; makro, mikro ve sembolik olmak üzere üç seviyede öğrenilmektedir (Johnstone, 2000; Sirhan, 2007). Öğrencilerin algoritmik soruları çözme biçimlerinin sesli düşünme protokolü aracilığıyla incelenmesi; kimyasal denge konusunun mikro ve sembolik düzeyde öğrenilmesinde öğrencilerin güçlükler yaşadığını göstermektedir. Bu nedenle mikro ve sembolik seviyeler ile bu seviyeler arasındaki ilişkinin öğrencilere açıkça öğretilmesi gerekmektedir (Sirhan, 2007). Öte yandan öğretmenin bir parçası olan problem çözme uygulamalarının da bu ifade edilenleri destekleyecek biçimde yapılandırılması önemlidir. Bu bağlamda problem çözümünde yalnızca sonuca değil sürece odaklanmanın değeri ve kimyanın soruların cevaplarını bulmak için algoritmaların uygulandığı bir alanın çok daha ötesinde olduğu söylenebilir (Phelps, 1996).

Algoritmik sorular, kimya konuları kapsamında yer almakta ve öğrencilerin bu soruları çözmeleri beklenmektedir. Ancak algoritmik soruların yalnızca matematiksel bir mantıkla çözülmesi, bu soruların kimya bağlamında kullanılma amacına hizmet etmeyeceği açıktır. Bu çalışmanın bulguları; özelde kimyasal dengeyle genelde ise kimya konularıyla ilgili algoritmik soruların öğrenme öğretme sürecinde kullanılmasında; soruda geçen kavramların ne anlama geldiğinin, değişkenlerin/verilerin nasıl yorumlanacağının, sorunun çözümünde kullanılan formüllerin/bağıntıların ve algoritmanın matematiksel mantığından ziyade kimyasal mantığının kavratılmasının önemli olduğunu dikkatlere sunmaktadır.

\section{KAYNAKLAR}

Akkus, H., Kadayifci, H. ve Atasoy, B. (2011). Development and application of a two-tier diagnostic test to assess secondary students' understanding of chemical equilibrium concept. Journal of Baltic Science Education, 10(3), 146-155.

Altun, M. (2000). İlköğretimde problem çözme öğretimi. Milli Eğitim Dergisi, 147.

Altun, M. ve Arslan, Ç. (2006). Illköğretim öğrencilerinin problem çözme stratejilerini öğrenmeleri üzerine bir çalışma. Uludağ Üniversitesi Eğitim Fakültesi Dergisi, 19(1), 1-21.

Balcı, A. (2010). Sosyal bilimlerde araştırma yöntem, teknik ve ilkeler. Ankara: Pegem Akademi.

Bayrakçeken, S., Canpolat, N., \& Çelik, S. (2011). Kimyanın doğası ve öğretimi. II. Ulusal Kimya Eğitimi Kongresi. 5-8 Temmuz 2011, Erzurum, Türkiye.

Bilgin, İ. ve Geban, Ö. (2006). The effect of cooperative learning approach based on conceptual change condition on students' understanding of chemical equilibrium concepts. Journal of Science Education and Technology, 15(1), 31-46.

Boujaoude, S. ve H. Barakat (2003). Students problem solving strategies in stoichiometry and their relationships to conceptual understanding and learning approaches. Electronic Journal of Science Education, 7(3), 23-29.

Bowen C. W. (1994). Think-aloud method in chemistry education. Journal of Chemical Education, 71(3), 184-190.

Cachapuz, A.F.C. ve Maskill, R. (1989). Using word association in formative classroom tests: Following the learning of Le Chatelier's Principle. International Journal of Science Education, 11(2), 235-246.

Chandrasegaran, A. L., Treagust, D. F., Waldrip, B. G. ve Chandrasegaran, A. (2009). Students' 
dilemmas in reaction stoichiometry problem solving: Deducing the limiting reagent in chemical reactions. Chemical Education Research and Practice, 10, 14-23.

Childs, P. E. ve Sheehan, M. (2009). What's difficult about chemistry? An Irish perspective. Chemistry Education Research and Practice, 10, 204-218.

Coştu, B. (2007). Comparison of students' performance on algorithmic, conceptual and graphical chemistry gas problems. Journal of Science Education and Technology, 16(5), 379-386.

Coştu, B. (2010). Algoritmic, conceptual and grapgical chemistry problems: A revisited study. Asian Journal of Chemistry, 22(8), 6013-6025.

Creswell, J. W. (2013a). Araştırma deseni. (Çev. Ed. Selçuk Beşir Demir) Ankara: Eğiten Kitap.

Creswell, J. W. (2013b). Nitel araştırma yöntemleri. (Çev. Ed. Mesut Bütün ve Selçuk Beşir Demir) Ankara: Siyasal Kitabevi.

Çelik, S., Canpolat, N., Pınarbaşı, T., Sözbilir, M. ve Bayrakçeken, S. (2007). Üniversite Öğrencilerinin Bazı Genel Kimya Konularını Kavramsal Öğrenme Düzeyleri. 1. Ulusal Kimya Eğitimi Kongresi. 20-22 Haziran 2007, İstanbul, Türkiye.

Çobanoğlu, E. O. (2013). Epistemoloji, bilimsel kavramların doğası, bilimsel bilgi ve özellikleri. Murat Demirbaş (Ed.), Bilimin doğası ve öğretimi içinde (s. 55-70). Ankara: Pegem Akademi.

Eğitim Reformu Girişimi (2014). Türkiye'de eğitimin politika öncelikleri: Eşitlik, ortaöğretim, öğretmenler, özel okul desteği. http://erg.sabanciuniv.edu/sites/erg.sabanciuniv.edu/files/Egitimin_Politika_Oncelikleri _BN_WEB.pdf (Erişim Tarihi: 2015, 20 Nisan)

Galbraith, G. (1998). Writing as a knowledge-constituting process. Torrance2, 9(2), 137-158.

Gultepe, N., Yalcin Celik, A. ve Kilic, Z. (2013). Exploring effects of high school students' mathematical processing skills and conceptual understanding of chemical concepts on algorithmic problem solving. Australian Journal of Teacher Education, 38(10), 105-122.

Hartman, J. R. ve Lin, S. (2011). Analysis of student performance on multiple-choice questions in general chemistry. Journal of Chemical Education, 88(9), 1223-1230.

Johnstone, A. H. (2000). Teaching of chemistry - logical or psychological? Chemistry Education: Research and Practice in Europa, 1(1), 9-15.

Kousathana, M. ve Tsaparlis, G. (2002). Students' errors in solving numerical chemicalequilibrium problems. Chemistry Education: Research and Practice in Europe, 3(1), 5-17.

Köğce, D., Özpınar, İ., Mandacı Şahin, S. ve Aydoğan Yenmez, A. (2014). Öğretim elemanlarının 21. yüzyıl öğrenen standartları ve yaşam boyu öğrenmeye ilişkin görüşleri. Dicle Üniversitesi Ziya Gökalp Eğitim Fakültesi Dergisi, 22, 185-213.

Kuusela, H. ve Paul, P. (2000). A comparison of concurrent and retrospective verbal protocol analysis. Am J Psychol., 113(3), 387-404.

Mei-Hung, C. (1993). Developing problem-solving skills in chemical equilibrium - a constructive model. http://files.eric.ed.gov/fulltext/ED362402.pdf (Erişim Tarihi: 2015, 12 Haziran).

Merriam, S. B. (2002). Introduction to qualitative research. Saharan B. Merriam (Ed.), Qualitative research in practice: Examples for discussion and analysis içinde (s. 1-17). San Francisco, CA: Jossey-Bass. 
Miles, M. B. ve Huberman, A. M. (1994). Qualitative data analysis: An expanded source book. California: SAGE Publications.

Nakhleh M.B. (1993), Are our students conceptual thinkers or algorithmic problem solvers? Journal of Chemical Education, 70, 52-55.

Nurrenberg, S. C. ve Pickering, M. (1987). Concept learning versus problem solving : Is there any difference? Journal of Chemical Education, 64(6), 508-510.

Overton, T., Potter, N. ve Leng, C. (2013). A study of approaches to solving open-ended problems in chemistry. Chemistry Education Research and Practice, 14, 468-475.

Öğrenci Seçme ve Yerleştirme Merkezi [ÖSYM] (2013). Lisans yerleştirme sınavı-2 kimya testi. http://www.osym.gov.tr/dosya/1-69255/h/lys2kimyatesti.pdf (Erişim Tarihi: 2015, 17 Eylül).

ÖSYM (2014). Lisans yerleştirme sınavı-2 kimya testi. http://dokuman.osym.gov.tr/pdfdokuman/2014/LYS/sorucevap/2014LYS2KiMYA220620 14.pdf (Erişim Tarihi: 2015, 17 Eylül).

ÖSYM (2015). 2015-Lisans yerleştirme sınavları (2015-LYS) sonuçları. http://dokuman.osym.gov.tr/pdfdokuman/2015/LYS/2015LYSSAYISALBILGILER30062015 .pdf (Erişim Tarihi: 2015, 17 Eylül).

Özden, M. (2007). Kimya öğretmenlerinin kimya öğretiminde karşılaştıkları sorunların nitel ve nicel yönden değerlendirilmesi: Adıyaman ve Malatya illeri örneği. Pamukkale Üniversitesi Eğitim Fakültesi Dergisi, 2(22), 40-53.

Özmen, H. (2008). Determination of students' alternative conceptions about chemical equilibrium: A review of research and the case of Turkey. Chemistry Education Research and Practice, 9, 225-233.

Papaphotis, G. ve Tsaparlis, G. (2008). Conceptual versus algorithmic learning in high school chemistry: The case of basic quantum chemical concepts part 1 . Statistical analysis of a quantitative study. Chemistry Education Research and Practice, 9, 323-331.

Parchmann, I., Broman, K., Busker, M. ve Rudnik, J. (2015). Context-based teaching and learning on school and university level. J. GarcÃa-MartÃnez, E. Serrano-Torregrosa (Ed.), Chemistry education: Best practices, opportunities and trends içinde (s. 259-276). Weinheim, Germany: Wiley-VCH Verlag GmbH \& Co.

Partnership for $21^{\text {st }}$ Century Learning (2015a). P21 Framework definitions. http://www.p21.org/storage/documents/docs/P21_Framework_Definitions_New_Logo _2015.pdf (Erişim Tarihi: 2015, 16 Eylül).

Partnership for $21^{\text {st }}$ Century Learning, (2015b). Critical thinking and problem solving. http://www.p21.org/about-us/p21-framework/260 (Erişim Tarihi: 2015, 16 Eylül).

Phelps, J. A. (1996). Teaching to enhance problem solving: It's more than the numbers. Journal of Chemical Education, 73(4), 301-304.

Quilez-Pardo, J. ve Solaz-Portoles, J. J. (1995). Students' and teachers' misapplication of Le Chatelier's Principle: Implications for the teaching of chemical equilibrium. Journal of Research in Science Teaching, 32(9), 939-957.

Randles, C. A. ve Overton, T. L. (2015). Expert vs. novice: approaches used by chemists when solving open-ended problems. Chemistry Education Research and Practice, 16, 811-823. 
Salta, K. ve Tzougraki, C. (2011). Conceptual versus algorithmic problem-solving: Focusing on problems dealing with conversation of matter in chemistry. Research in Science Education, 41(4), 587-609.

Sirhan, G. (2007). Learning difficulties in chemistry: An overview. Journal of Turkish Science Education, 4(2), 2-20.

Sözbilir, M., Pınarbaşı, T. ve Canpolat, N. (2010). Prospective chemistry teachers' conceptions of chemical thermodynamics and kinetics. Eurasia Journal of Mathematics, Science \& Technology Education, 6(2), 111-120.

St Clair-Thompson, H., Overton, T. ve Bugler, M. (2012). Mental capacity and working memory in chemistry: Algorithmic versus open-ended problem solving. Chemistry Education Research and Practice, 13(4), 484-489.

Staver, J. R. ve Lumpe, A. T. (2006). Two investigations of students' understanding of the mole concept and its use in problem solving. Journal of Research in Science Teaching, 32(2), 177-193.

Şimşek, Ü., Doymuş, K., Doğan, A. ve Karaçöp, A. (2009). İşbirlikli öğrenmenin iki farklı tekniğinin öğrencilerin kimyasal denge konusundaki akademik başarılarına etkisi. GÜ, Gazi Eğitim Fakültesi Dergisi, 29(3), 763 - 791.

Talim Terbiye Kurulu Başkanlığı [TTKB] (2011). Ortaöğretim 11. sınıf kimya dersi öğretim programı. ttkb.meb.gov.tr/www/ogretim-programlari/içerik/72 (Erişim Tarihi: 2015, 17 Eylül).

Teddlie, C. ve Yu, F. (2007). Mixed methods sampling: A typology with examples. Journal of Mixed Methods Research, 1(1), 77-100.

Temel, S. ve Morgil, í. (2007). Kimya eğitiminde laboratuarda problem çözme uygulamasının öğrencilerin bilimsel süreç becerilerine ve mantıksal düşünme yeteneklerine etkisi. Dokuz Eylül Üniversitesi Buca Eğitim Fakültesi Dergisi, 22, 89-97.

Temel S. ve Morgil, i. (2012). Kimya laboratuvarında problem çözme uygulamaları. Ankara Üniversitesi Eğitim Bilimleri Fakültesi Dergisi, 45(2), 55-76.

Trilling, B. ve Fadel, C. (2009). 21st Century skills learning for life in ourtimes. San Francisco: Jossey-Bass.

Tunç, T., Akçam, H. K. ve Dökme, İ. (2011). Üç aşamalı sorularla sınıf öğretmeni adaylarının bazı temel fen kavramları hakkında sahip oldukları kavram yanılgıları. GÜ, Gazi Eğitim Fakültesi Dergisi, 31(2) 817-842.

Weerawardhana, K. W. P. A. (2006). Teaching strategies that support student development of conceptual understanding of chemical equilibrium using visualization software. (Doctoral dissertion, University of Wollongong, Australia). http://ro.uow.edu.au/theses/737 (Erişim Tarihi: 2015, 17 Eylül).

Woldeamanuel, M. M., Atagana, H. ve Engida, T. (2014). What makes chemistry difficult? African Journal of Chemical Education (AJCE), 4(2), Special Issue (Part I), 31-43.

van Someren, M. W., Barnard, Y. F. ve Sandberg, J. A. C. (1994). The think aloud method: A practical guide to modelling cognitive processes. London: Academic Press.

Yılmaz, A., Tuncer, G. ve Alp, E. (2007). An old subject with recent evidence from Turkey: Students' performance on algorithmic and conceptual questions of chemistry. World Applied Sciences Journal, 2(4), 420-426. 
EK-1

\section{SESLI DÜŞÜNME YÖNERGESI}

1) Size verilen soruları sesli olarak okuyunuz ve çözmeye çalışınız.

2) Sizden beklentimiz; problemi çözerken daima yüksek sesle düşünmeniz.

3) Problemi çözümünü kağıt-kalem kullanarak yapınız.

4) Problemin çözümünü kağıda görülebilecek şekilde net olarak yazınız.

5) Sayısal cevaplarınızın doğruluğundan ziyade problemi nasıl çözdüğünüzle ve izlediğiniz adımlarla ilgileniyoruz. Bu nedenle düşüncelerinizin tamamını takip edebilmemiz için lütfen size önemsiz, saçma, basit veya söylemeye gerek olmayacak kadar açık ve net gelen düşüncelerinizi dahi sesli olarak ifade ediniz.

6) Belirli bir kelimenin anlamını öğrenmek istediğinizde sorabilirsiniz. Ancak problem çözümünde izlediğiniz adımların veya elde ettiğiniz sonuçların doğruluğu ya da yanlışlı̆ı̆ konusunda size herhangi bir şey söylenmeyecektir. 


\section{SUMMARY}

Today's societies expect their education systems to impart the skills and competencies that are called $21^{\text {st }}$ century skills to their students. The $21^{\text {st }}$ century skills are classified as life and career skills, learning and innovation skills and digital literacy skills (Partnership for $21^{\text {st }}$ Century Learning, 2015-a; Trilling \& Fadel, 2009). These skills are comprised of many sub-skills and competencies. One of them is problem solving skill (Partnership for $21^{\text {st }}$ Century Learning, 2015-b).

Problem solving is an important area of research for educators. In chemistry education, problem solving has been viewed to be an important part of curriculum development and as an assessment tool and has become the subject of much research in the field of chemistry education (MeiHung, 1993; St Clair-Thompson, Overton \& Bugler, 2012; Temel \& Morgil, 2012). When these studies and problem solving activities performed at schools within the context of chemistry courses are examined, it is seen that problem solving activities are usually based on algorithmic and conceptual problems (Coştu, 2007; Gultepe, Yalcin Celik \& Kilic, 2013; Salta \& Tzougraki, 2011). Such questions also asked in the national exams in Turkey that should be taken to progress through school towards higher levels. The questions asked in the national exams usually include conceptual, algorithmic and graphical questions (Ölçme Seçme ve Yerleştirme Merkezi [ÖSYM], 2013, 2014). Thus, in the class, teachers put great emphasis on these types of questions to prepare their students for the national exams. Of these types of questions, algorithmic questions were selected as the interest of this study. Within the framework of this study, it was investigated how students solve algorithmic questions. To this end, think-aloud protocol was used as the purpose was not to focus on the result but the process. By analyzing the thoughts generated by the students while solving the problems, it was intended to elicit the conceptions of the students. Thus, answer to the following question was sought within this study:

What are the thoughts generated by the $11^{\text {th }}$ grade students during the process of solving chemical equilibrium algorithmic questions about the related concepts and the definition of the relationships between these concepts, interpretation of variables/data, the use of formulas/connection and algorithm?

This study was designed in the form of a case study, one of the qualitative research methods. The study group was determined by using purposive sampling selection method. The study group was selected from among the $11^{\text {th }}$ grade students of a high school (called Anatolian High School) that accepts the students who get high scores from the national exam to pass from secondary school to high school. The reason for the selection of this school is that it accepts its students on the basis of their high scores taken from the national exam and that it is a type of high school believed to give high quality education (Eğitim Reformu Girişimi, 2014). The reason for selecting the participants from among $11^{\text {th }}$ graders is that the topic of this study that is chemical equilibrium is taught within the curriculum of $11^{\text {th }}$ grade chemistry course.

Six students participated in the study. As a criterion for the selection of these students, their chemistry course achievement level was taken. The students' chemistry achievement was determined on the basis of the opinions of the chemistry teacher and their chemistry course achievement scores taken in their previous term. For this purpose, chemistry course achievement scores of all the $11^{\text {th }}$ grade students in the school were examined. It was determined that their achievement scores range between 70 and 100. Then the students were divided into three groups on the basis of their achievement scores as follows: the achievement level of the students whose scores are 100-90 is high, the achievement level of the students whose scores are $90-80$ is medium and achievement level of the students whose scores are 80-70 is low. Then two students from each of these three categories were selected on the basis of the chemistry teacher's suggestions and on voluntary basis.

The data of the study were collected four weeks after the topic of chemical equilibrium was taught in the class in the second term of 2014-2015 school year. For this purpose, the students were asked to solve the four open-ended questions given in the algorithmic question form by considering the issues stated in the think-aloud protocol. The questions in the algorithmic question form were developed as a result of a literature review. Then their final forms were given after seeking the opinions of an expert working in the field of chemistry and chemistry education and two chemistry teachers working in the Anatolian High School with work experience of 15 and 18 years. While solving the 
algorithmic questions, the students used paper, pencil and calculator. The time period spent by students on solving the problems ranged from 20 minutes to 45 minutes. The interviews were recorded by using a tape-recorder.

The data of the study consist of students' audio recordings and papers on which they solved the problems. During the data analysis process, first the students' audio recordings were transcribed. This process was conducted simultaneously considering the papers on which the questions were solved and thus, question solving protocol for each student was obtained by combining audio-recordings and written data on the papers. The protocols were checked for their accuracy. The data of the study were analyzed through descriptive analysis. In this respect, the data collected were analyzed and interpreted under four themes being definition of the concepts and the relationships between these concepts, interpretation of the variables/data involved in the problems, construction of formulas/connections and use of algorithm by taking the opinions of two experts working in the field of measurement and evaluation. In the determination of these themes, the steps involved in the solution of an algorithmic problem were taken into consideration.

At the end of the study, it was concluded that the students' explanations about the important concepts (chemical equilibrium, equilibrium constant, Le Chatelier principle etc.) involved in algorithmic problems related to chemical equilibrium are inadequate, that the state of whether having solved similar problems before has important influence on the interpretation of the variables/data involved in the questions, that formulas/connections that need to be used during problem solution could be used to a great extent but their understanding of the place of these formulas/connections in chemistry is not very sophisticated and they mostly used missing or false algorithms in the solutions of the problems yet despite these erroneous use, they were able to find correct outcomes for some of the problems. In light of these findings of the study, it can be argued that solving algorithmic problems only on the basis of a mathematical logic may not serve their understanding within the context of chemistry. In this regard, the findings of this study indicate that rather than mathematical logic of the algorithm, its chemical logic should be taught to students so that they can better understand what the concepts involved in the solution mean, how variables/data should be interpreted and how formulas/connections should be used within the context of algorithmic problems related to chemistry. 